\title{
Fiesta y regozijo. Las fiestas de toros en España y su defensa en 1570
}

\author{
Gonzalo SANTONJA GÓMEZ-AGERO \\ Universidad Complutense de Madrid \\ gsantonj@pdi.ucm.es \\ Valentín MORENO GALLEGO \\ Real Biblioteca
}

\section{RESUMEN}

El objeto del artículo es comentar y editar un memorial presentado a instancias de la Monarquía Hispánica, datable en 1570, en defensa de las fiestas de toros. Su contexto es el de la prohibición pontificia de Pío V, mediante bula, en 1567. En el Archivo General de Simancas se halla el memorial en redacción primigenia y en el Archivo-Biblioteca Zabálburu (Madrid) la versión definitiva, para ser utilizada en Roma por el embajador hispano ante la corte papal. El documento está dirigido al doctor Juan López de Velasco. Estos aspectos, y otros, se analizan antes de editarse por primera vez, en su integridad, la versión completa del memorial tras editarse en 2012 la primigenia.

Palabras clave: Tauromaquia, fiestas de toros, España, prohibiciones papales, Felipe II.

\begin{abstract}
The purpose of this article is to discuss and edit a document ("memorial") in defence of the Bullfighting Feast, dated in 1570, and wrote at the request of Spanish Monarchy. The pontificial Pius V ban by papal bull in the year 1567 is the context of this memorial. Document's initial writing is kept in General Archive of Simancas and the final version, used for the Roman curia by Spanish ambassador in Rome, is in Zabálburu Archive-Library (Madrid). Document from Simancas is addressed to the doctor Juan López de Velasco. After an incomplete version, corresponding to initial version, published in the year 2012, now the overall document (final version) is edited by first time, and some related aspects are analized also.
\end{abstract}

Key words: Tauromachy, bullfighting Feast, Spain, papal bans, Felipe II. 
La bula pontificia de 1567 contra los festejos taurinos, causó, evidentemente, repercusión en España ${ }^{1}$. Dada en Roma el primero de noviembre de 1567, segundo año del pontificado de Pío V (1504-1572), casi vino a coincidir el motu propio ${ }^{2}$ con unos pocos meses de diferencia-, con las muertes y los consiguientes lutos del príncipe Don Carlos y de la reina Isabel de Valois. La primera muerte fue en 24 de julio de 1568 y la segunda en tres de octubre de dicho año. Por tanto, su efecto prohibitorio se vio muy amortiguado por los lutos reales ${ }^{3}$. Pero antes de dichas muertes, en junio de 1568, el corregidor de Soria consultó al Consejo Real si se podían celebrar toros y éste manifestó que se excusase esta fiesta. Es decir, antes de ninguna toma de posición por parte de la Corona, la bula produjo prevenciones, ya que la misma era prohibitoria con carácter universal, excomulgándose a los príncipes que la permitieran e incluso vetando a los hombres de armas enfrentarse a los toros.

Sin embargo, las nuevas bodas de Felipe II, con Ana de Austria, y sus festejos respectivos, cambiaron el panorama y se pasó del conocimiento de la bula o motu propio, a explicarse su inconveniencia. En efecto, tras la firma de las capitulaciones matrimoniales en Madrid el 24 de enero de 1570 y en torno a los desposorios del doce de noviembre de ese año, el ambiente cortesano alejó el luto y se requería de la "fiesta y regozijo" que eran las fiestas de toros, en expresión escrita muy repetida en la época, donde pueblo y nobleza participaban, en una realidad manifestada durante todos los Austrias. Incluso, sobre todo con los valimientos de Lerma y Olivares se convertirán, tanto para reyes como para validos, en instrumento político del ocio cortesano regio o del propio valido ${ }^{4}$.

\footnotetext{
${ }^{1}$ A. García Añoveros (2007a). En los caps. X y XI se ocupa extensa y respectivamente de los documentos pontificios y de los eclesiásticos en relación a la fiesta de toros.

2 Bullarum (1862), pp. 630-631. Se ha consultado ejemplar en Biblioteca Nacional de España (BNE), 12/701994, pp. 630-631, donde se edita el texto completo de la bula pontificia o motu propio, documento papal relativo tanto a materias de fe como a cuestiones generales de interés para el santo padre, expedido por la cancillería apostólica, y que portan el sello del titular de la cátedra de Pedro en ese momento. Es documento generado por voluntad propia del pontífice, de ahí este sobrenombre de motu propio.

${ }^{3}$ Justo poco antes del motu propio, en 1565 , se cambiaron algunas disposiciones legales relativas a los lutos de personas reales, restringiéndose las muestras públicas de duelo a más de seis meses para el titular del trono, su consorte e hijos, y para el resto de la familia real serían durante menos de medio año; y sólo por las primeras podría ponerse paños y estrados negros en balcones y fachadas (J. Varela, 1990, p. 35).

${ }^{4}$ B. García García (1998), pp. 143-172. Ya el conde de las Navas (1985), pp. 112-113 y 129, menciona un notable festejo en Lerma costeado por el duque en el que participaron caballeros muy principales, según se sabe por la relación que hizo el licenciado Pedro de Herrera, Traslación del Santissimo Sacramento..., Madrid, Juan de la Cuesta, 1618. Este 2016 la Unión de Bibliófilos Taurinos tiene prevista edición en facsímil con estudio preliminar.
} 


\section{Trasfondo político de la bula prohibitoria y del memorial: las relaciones Corona-Santa Sede}

En 1570, la cuestión de la bula, tras los lutos, ya se hacía incómoda por su carácter prohibitorio y dada la demanda popular de festejos desde villas y ciudades. Fue entonces cuando se alzaron voces en contra, incluso desde las mismas Cortes de Castilla, que en febrero se dirigieron a Su Majestad para que interpelara al pontífice y que éste permitiera correr toros para que "las ciudades den sus toros acostumbrados" ". Y es que había confusión pues ese año de 1570 hubo festejos taurinos, y algunos muy sonados, con motivo de las bodas regias, como los del mismísimo Arzobispo de Sevilla, que costeó una corrida el 12 de noviembre -al igual que otros cabildos eclesiásticos- pero otros festejos fueron suspendidos por la bula como los de Segovia del 12 de noviembre, o los del 25 de octubre de Burgos. Aparte de la voluntad del monarca, el sentimiento generalizado era a favor de la celebración de las fiestas de toros y lo mismo ocurrió en América, donde se siguieron corriendo pese a la promulgación de la bula que se hizo en Lima, y en México también se corrieron tras ella. En cambio, en Portugal se acató y cumplió el motu propio, y eso que el rey Don Sebastián gustaba mucho de lidiar a caballo con rejones en las touradas. Por tanto, se imponía clarificar la situación a favor de los festejos, desde el punto de vista español, y para ello debía modificarse la actitud vaticana. Así, el 23 de julio de ese 1570 el secretario real Antonio de Eraso instaba al embajador español ante la Santa Sede, don Juan de Zúñiga, príncipe de Pietrapercia, para que pidiera al Papa la modificación del breve que prohibía las corridas de toros. En este contexto, empezaron a aparecer memoriales en su defensa, algunos de los cuales se le hicieron llegar a Zúñiga para que tuviera armas argumentativas ante la curia vaticana pues en ella, como se verá, poderosas voluntades se empleaban a fondo contra la costumbre de correr toros. Aquí publicamos uno de ellos, inédito hasta ahora, conservado en el Archivo-Biblioteca Francisco de Zabálburu de Madrid, y recuperamos la versión primigenia, custodiada en el Archivo de Simancas.

La primera batalla con Roma duró un quinquenio pues hasta 1575 no se produjo el breve pontificio de Gregorio XIII, en el que se atenuaba la prohibición. Precisamente, existe en este archivo una minuta de Zúñiga al monarca, borrador de la carta que dirigió al rey en septiembre de 1575 , donde dice haber recibido hacía unos meses correspondencia regia ordenándole que siguiera intercediendo ante el santo padre con relación a la prohibición del correr toros que hizo "la santa memoria de pio quinto". Dice en efecto Zúñiga haber visto memoriales sobre ello y que ya había replicado al papa que no prohibiese la asistencia de clérigos para ver los toros y que dejase que se corriesen en día de fiesta ${ }^{6}$. No se lograron entonces

\footnotetext{
${ }^{5}$ García Añoveros (2007a), p. 311.

${ }^{6}$ Archivo-Biblioteca Zabálburu, caja 56-exp. 59.
} 
ambas cosas, no obstante, se levantó la condena y prohibición universal en el breve de ese año. Pero la cuestión fue largamente disputada y hasta 1596, con Clemente VIII, no se consiguió rebajar casi del todo el veto vaticano.

Estos memoriales presentan dos niveles de interés. Obviamente desde la perspectiva de historia de la tauromaquia, como reacción a la prohibición vaticana, pero también desde la de las relaciones entre la Santa Sede y la Monarquía Hispánica en ese momento, en 1570, un momento difícil por empezar a desarrollarse unos años antes el programa de confesionalización de la Monarquía impulsado por Felipe II, ambicioso programa ideológico que en diversos aspectos chocó con las perspectivas de Roma. Paralelamente, en la Europa católica se estaban aplicando las nuevas directrices contrarreformistas salidas de Trento. En este sentido, a Pío V (1566-1572) se le ha valorado como el primer pontífice de la Contrarreforma, que en unión de sus sucesores, Gregorio XIII y Sixto V, sentó las bases de la Europa postridentina en lo religioso, con una imagen de fuerza del poder pontificio que estos papas impulsaron.

De los tres pontífices, con Pío $\mathrm{V}$ tal vez fueron las relaciones más tensas pues Gregorio XIII (1572-1585) había sido legado en Madrid y ayudó a la expansión de las órdenes regulares españolas y el último apoyó incluso económicamente la fallida empresa de Inglaterra. Gregorio XIII siempre estuvo apoyando a Antonio Pérez ${ }^{7}$, que encabezará la antigua facción ebolista, ahora papista, en la corte de Felipe II, tras morir en 1573 el príncipe de Éboli, Ruy Gómez de Silva, y que estará en confrontación con el partido hoy llamado castellanista. Pero con Pío V hubo situaciones especialmente difíciles, sobre todo por el control de la Inquisición, cuyos órganos fueron motivo entonces, y en las décadas siguientes, de la pugna entre el partido castellanista y la facción papista. Tras el asunto de la prisión del primado de Toledo, Bartolomé Carranza, intervino el nuncio, monseñor Giovanni Battista Castagna, que apaciguó los ánimos y ayudó a superar la crisis. Pío V, el papa Ghislieri, fue así, en diversos aspectos, heredero del antiespañolismo de Paulo IV; aunque en grandes cuestiones internacionales se situó junto a Felipe II, excomulgando a Isabel de Inglaterra o impulsando la Liga Santa frente a los otomanos para la batalla de Lepanto, en otras materias sentía menoscabada la jurisdicción vaticana frente a la pujanza filipina y no gustaba de la fuerte presencia hispana en Italia.

\section{La cuestión de la autoría}

Del memorial que protagoniza este texto hay conservadas dos versiones. Una primigenia, reducida de contenido con respecto a la final, conservada en el Archivo

${ }^{7}$ G. Marañón (1947), pp. 119-143. 
General de Simancas y una definitiva, más amplia, custodiada en el ArchivoBilioteca Zabálburu, de Madrid. La primera versión la publicó Santonja ${ }^{8}$, y la definitiva se publica ahora, aunque fue transcrita en el verano de 2011 por Moreno desconociéndose entonces la existencia de la primera versión, dirigida "al doctor Velasco", Juan López de Velasco ("Memorial, çerca del propio motu de $\mathrm{Su}$ Santidad en lo de los toros"). En el anexo se editan las dos para su consideración comparada por parte del lector.

El receptor de la primigenia consta en el margen izquierdo del último folio, en sentido vertical, en mano de época. ¿Por qué se remitió al doctor Velasco?, cabe preguntarse. Velasco muere el mismo año que Felipe II, en 1598, pocos meses antes que el monarca y, en 1570, fecha muy adjudicable al memorial, contaba treinta y tantos años, como mucho cuarenta. Era persona de amplias letras humanas y es muy de suponer que se le envió para que emitiera su parecer al texto y diera su aprobación, para que a su vez él lo presentara a la majestad del rey, que tenía la última palabra para que fuera usado como argumentación en otras instancias. Hay que recordar que el doctor Velasco gozaba de la estima real a efectos de letras históricas o literarias y su aprobación. En 1570 estaba en el Consejo de Indias desde hacía siete años, trabajando en la labor del Código Ovandino, siendo nombrado al año siguiente cronista del Consejo. Al muy poco tiempo falleció el cosmógrafo Alonso de Santa Cruz, en 1572, y se le designó cosmógrafo real, uniendo en su persona las dos calidades de cronista de Indias y cosmógrafo real. Intervino también en la preparación de las famosas Relaciones topográficas de Felipe II. Estos años son los de mayor confianza regia a la hora de ocuparse de textos ${ }^{9}$ pues en 1573 se le asignaba la censura de párrafos de algunas obras prohibidas por la Inquisición, con el fin de permitir su circulación corregida en ediciones "castigadas", y se ocupó así de el Lazarillo de Tormes o de textos de Cristóbal de Castillejo y de Bartolomé de Torres Naharro. Años antes, había dado a la luz en Burgos, en 1562, una Orthographia y pronunciación castellana. En 1574/75 escribía una obra americanista importante, inédita hasta finales del siglo XIX, la Geografía y descripción universal de las Indias Occidentales. Hasta el final de sus días estuvo en el servicio real pues de 1588 a 1596 ocupó la secretaría del Consejo de Hacienda ${ }^{10}$ y aunque en 1596 fue multado y privado de la secretaría por irregularidades que se hallaron, se le perdonaron penas y fue nombrado secretario de Cruzada, gratificándosele en compensación, es decir, hasta el final gozó del aprecio real.

En cuanto al texto, la versión de Simancas está muy falta pues solo se forma con dos hojas, cuatro planas de texto, con muchas tachaduras, y la versión definitiva

${ }^{8}$ Cfr. AGS, Patronato Real, legajo 22-exp. 100. La edición de G. Santonja (2012), pp. 168173, transcripción, reproducción fotográfica en pp. 174-177.

9 J.A. Pérez Rioja (1958), pp. 7-38.

10 J. Martínez Millán (1998), p. 310. 
es en limpio y con ocho planas más de texto, cuatro folios más. Acaba la versión primigenia al tratar de los intervinientes a pie y a caballo: “..., es el exerçiçio en sí muy bueno y muy loable de destreza y de ánimo y muy propio de hombres y de caballeros [y en que no solo, tachado] que no solo deue/// [pérdida de papel]. Mientras que el texto definitivo desarrolla por extenso lo escrito: "Concurren espeçialmente en los lugares principales en esta fiesta personas a caballo que puedan acorrer [id est, socorrer] y ualer a los de a pie, y los de a pie ansimismo son muchos y entre ellos ay hombres muy diestros que con seguridad y facilidad valen y defienden del toro a los otros, de manera que si algún peligro o daño sucede ni es de parte de la fiesta ni de aquellos a cuyo cargo es el proveerlo, sino por culpa grande de aquel a quien suçede el caso". Y continúa. Por cierto, el párrafo reproducido es de capital relieve interpretativo pues refleja con obviedad lo importante del toreo a pie a mitad del siglo XVI, al afirmarse que los toreadores son socorridos por los de a caballo y a su vez los toreadores socorren a los de a caballo, realidad ésta siempre admitida pero no la primera, repetimos: "los de a pie ansimismo son muchos y entre ellos ay hombres muy diestros que con seguridad y facilidad valen y defienden del toro a los otros".

El estilo de redacción es claramente de defensa y predominio de la jurisdicción civil y real frente a la eclesiástica. Es de alto interés desde este enfoque pues es una muestra evidente del estilo de las altas esferas reales castellanistas. Se argumenta constantemente que el papa ha sido mal aconsejado en esta materia, que se ha precipitado, que no ha escuchado voces realmente autorizadas, y otras coletillas argumentales propias de uno de los más altos representantes de la facción castellanista: Mateo Vázquez de Leca, el secretario de Felipe II, tan rival de Pérez (Lovett, 1978), que finalmente se hizo con el control de las instancias inquisitoriales en su estructura burocrática. Ello se produjo en 1581 tras ceder el cardenal Gaspar de Quiroga, tan vinculado a la derrotada facción papista tras la caída de Antonio Pérez, al que reconocía deber su carrera (Marañón, 1947: 121, Pizarro, 2004), y que entonces entregó la secretaría de la Suprema Inquisición a Vázquez, en la época de mayor ascenso de éste, cuando eran clientes suyos el conde de Chinchón o Vázquez de Arce. En otros memoriales del secretario regio se repite la idea del mal asesoramiento pontificio en cuestiones graves y las consecuencias de ello, caso del célebre de diciembre de 1578 donde otorga a la Monarquía un sentido providencialista amenazado por un poder papista mal aconsejado. No obstante, aunque pudiera ser el original de su pluma, es muy arriesgado atribuirle la autoría del memorial que nos ocupa, pues se halla sin firmar, a pesar de tener todas las trazas de su estilo. Siendo dudoso si es de su mano el original, lo que sí parece seguro es que es uno de los que se le hizo llegar a Pietrapercia para que se sirviera de ellos en sus argumentaciones frente a la curia. En el manuscrito en que se halla hay otros textos en italiano, vecinos del nuestro. Es una copia en limpio, de mano 
de escribano, y dicha mano es del XVI, coetánea a los hechos, sin embargo, se encuentra en un volumen manuscrito ${ }^{11}$ que contiene también documentos muy posteriores. El memorial está en un manuscrito foliado, yendo su foliación del folio 380 recto al 385 vuelto, haciendo el documento $\mathrm{n}^{\circ} 37$. Se trata el volumen de un manuscrito que se abre con cuestiones de política internacional, avisos políticos, asuntos de letras humanas relativas a santos padres, y sigue muy diverso de materias. Los documentos vecinos son una relación de historiadores contrarios a Carlos V, con referencias a Paolo Giovio ( $\mathrm{n}^{\circ} 36$ ), en italiano, y el 39 es una relación sobre Portugal igualmente en italiano, aunque el 38 es una carta de 1583 al duque de Medina Sidonia en español.

El memorial es de 1570, según las referencias concretas a las personas reales y la referencia a las bodas regias de Felipe II con Ana de Austria. Si el memorial lo redactó Vázquez es imposible de saber, aunque es una hipótesis factible. El caso es que tanto los papeles de don Juan de Zúñiga como parte de los papeles de Estado de Mateo Vázquez se hallan en Zabálburu y, tal vez, por tanto, el memorial pudiera ser una temprana muestra del castellanismo vazquiano antes de acabar liderando la facción, muy consolidada antes en el ámbito cortesano por el tercer duque de Alba, cabeza de la misma. O puede ser de otra autoría. Para cuando muere don Fernando Álvarez de Toledo (enero de 1582) es cuando Mateo Vázquez es consciente de su gran protagonismo en esta facción cortesana de poder, sintiéndose muy fortalecido tras regresar de Lisboa con motivo de la incorporación de Portugal a la Monarquía. La evolución y confrontación de ambas corrientes, la papista y la castellanista, ha merecido amplios estudios, pudiendo servir por muestra, como general y primera aproximación, ya clásica, la dibujada extensamente en el volumen preliminar de estudio de la edición que la Junta de Castilla y León hizo de la Historia de Felipe II de Luis Cabrera de Córdoba ${ }^{12}$. Hay que indicar que cuando se redacta el original del memorial estaba Vázquez al servicio del cardenal Diego de Espinosa, en tiempo de su presidencia del Consejo Real, desde septiembre de 1565 hasta 1572 en que pasó al despacho regio. Muerto Espinosa en septiembre del dicho 1572, pasó inmediatamente al servicio directo del monarca, que le ordenó hacer inventario de los papeles del cardenal y que custodiara los papeles de su patrón ${ }^{13}$. Antes de pasar al servicio de Espinosa estuvo en el de Juan de Ovando, entonces provisor del arzobispo sevillano Fernando de Valdés, y gracias a ello tuvo conocimiento de la administración eclesiástica en muy alto grado. Espinosa fue el gran impulsor del desarrollo del confesionalismo hispano durante el período 1565-1572 y en esta

\footnotetext{
${ }^{11}$ Archivo-Biblioteca Francisco de Zabálburu (Madrid), caja 241.

12 J. Martínez Millán (1998), pp. 133-138. Sobre la transformación de la facción ebolista en papista y de cómo se formó y respondió la castellanista interesa todo el volumen, que tiene en gran parte como trasfondo la pugna entre ambas corrientes cortesanas de poder.

${ }^{13}$ J. Martínez Millán (1998), p. 137. Se remite al Instituto Valencia de Don Juan (Madrid), envío 56-exp. 8, y la relación de los papeles en envío 38-exp. 125.
} 
tarea ${ }^{14}$ participó Vázquez con eficacia. Justo en esos años sesenta en que está a su servicio se ejecuta el giro ideológico de la Monarquía Hispana tras la llegada al trono de Felipe II: la reforma de órdenes religiosas, la implantación de las disposiciones tridentinas, la mejora de la predicación y catequesis diocesanas, la formación del clero, etc, todo ello bajo estricto control regio ${ }^{15}$ y en este amplio frente habrá muchas aristas de fricción con Roma, que tuvo la necesidad de defender sus intereses con un partido papista cercano al soberano debido a los agudos enfrentamientos jurisdiccionales entre la Iglesia y el monarca. Este es el contexto histórico de la célebre bula De salute gregis $\left(1^{\circ}\right.$ de noviembre de 1567$)$ y el del memorial que se edita y comenta.

Un hecho que no es baladí con relación a Mateo Vázquez y sus recelos hacia la facción papista es que en 1568, gracias a su patrón Espinosa, fue nombrado secretario del Consejo de Inquisición para la corona de Aragón, pudiendo vivir propiamente el influjo de Antonio Pérez. Tras la vuelta del soberano a Castilla, tras la agregación de Portugal, es cuando Vázquez alcanza así su cenit ${ }^{16}$, aunque por poco tiempo pues hacia mitad de los ochenta hay una alteración en la administración de la gracia real al surgir nuevos patronos cortesanos ajenos a su ámbito y que instalaron a sus clientes o criaturas en puestos claves, relegándose a los de Vázquez. No obstante, perteneció al exclusivo grupo que formaba la llamada Junta de Noche, creada en 1585, junto con un muy fortalecido conde de Chinchón ${ }^{17}$, y además don Cristóbal de Moura, don Juan de Idiáquez y el mismo don Juan de Zúñiga. Aunque con ellos Mateo Vázquez estaba en el máximo órgano de gobierno, el verdadero triángulo de poder estaría concentrado en Moura, Idiáquez y Chinchón, que en los años finales del reinado llevarían los asuntos de Portugal y Castilla, Flandes y septentrión y Aragón e Italia, respectivamente ${ }^{18}$. El declive definitivo de Mateo Vázquez vino tras el desastre de la Armada contra Inglaterra pues desde septiembre de 1588 no acudió a Palacio al caer enfermo de gravedad. En ese octubre ordenó el rey que se hiciera la Junta en el aposento del secretario, en canto de cisne de su poder, falleciendo en el ocaso del mismo a inicios de mayo de 1591. Si seguimos con la hipótesis vazquiana de la autoría, hay que señalar que es

\footnotetext{
${ }^{14}$ J. Martínez Millán (1994), pp. 189-228, y (1998), pp. 103-131.

15 J.L. Gonzalo (2005), pp. 817-818. J. Martínez Millán (1998), p. 110, señala: “El proyecto iniciado por Felipe II a su vuelta a la península fue asumido por Diego de Espinosa estableciendo una correlación definitiva entre la confesión católica y la justificación política de la Monarquía hispana”.

${ }^{16}$ J. Martínez Millán (1998), pp. 219-223, para el poder de Mateo Vázquez en los primeros años ochenta y el auge del partido castellanista.

${ }^{17}$ S. Fernández Conti (1994), pp. 229-270.

${ }^{18}$ F. Bouza (1997), pp. 3-15 y 18-33. Trata de cómo la vinculación de Mateo Vázquez a estas juntas hizo que sus papeles no pasaran a Simancas y permanecieran en Madrid, p. 11.
} 
evidente que el aprendizaje junto al cardenal Espinosa, en el manejo de papeles de gobierno, fue capital en su ascenso y en su visión castellanista frente a Roma ${ }^{19}$.

Por tanto, visto el contexto político de las relaciones España-Santa Sede de nuestro memorial protaurómaco, en ese trienio $1567 / 70$ ya se manifiesta con claridad la existencia de un partido cortesano vaticanista y de su opuesto castellanista, siendo el documento que se edita, en su versión completa, una muestra evidente de la segunda facción, como bien refleja su contenido, aparte los aspectos taurómacos de interés intrínseco. Por ello, sin un mutuo consenso entre el poder real y el pontificio era imposible que la bula fructificara pues ambos poderes, expansivos, se equilibraban con sus respectivos ámbitos y sus zonas de coincidencia y por tanto era papel mojado cualquier disposición no consensuada. Antes de abordar el contenido del memorial es conveniente ver el contexto italiano de la bula para situarla en sus coordenadas con exactitud.

\section{Marco italiano de la bula pontificia}

Con respecto a la bula pontificia, hubo obviamente unos antecedentes italianos. Primero, el rechazo a la celebración de ciertos hábitos autóctonos desarrollados en Italia que no eran al uso hispano y que no tenían que ver con presencia española pues eran medievales, caso de alguno producido en el monte Testaccio, cercano a Roma. Durante los carnavales medievales se solían desarrollar unos juegos, los famosos goichi di Testaccio, presididos por el papa, donde se corrían osos, cerdos y también toros, y que derivaron con el tiempo en despeñarlos por el monte o colina. Con el paso del tiempo resultaron de especial dureza, máxime para muchas mentes cultas italianas de entonces, dadas a refinamientos urbanos alejados por un lado del elitismo caballeresco de la nobleza hispana, tan cercana aún a lo bélico, y por otro de los regocijos populares españoles, amantes de las confrontaciones de lucha de poder a poder. Estos festejos autóctonos pronto se prohibieron efectivamente en Italia y hay testimonios manuscritos de cómo era el llamado juego del despeñadero en Roma ${ }^{20}$.

Desde luego, estos festejos no eran del agrado de Pío V pues hay que recordar que no era hombre en general de holganzas, ya que era un dominico muy rigorista, de una austeridad de vida que precisamente le llevó a los altares como santo a principios del XVIII. En estos festejos se veía demasiado la huella de lo pagano, del circo romano antiguo, del uso de la violencia extrema en manifestación festiva y por ello "irritaba tanto a Su Santidad la asociación de toros y festividad religiosa,

\footnotetext{
${ }^{19}$ A. Lovett (1973), pp. 241-261.

${ }^{20}$ D. Ruiz Morales, 1962: 23-26, comenta un manuscrito del siglo XVII donde se recogen las razones de su prohibición en Roma. Se trata de un manuscrito que reproduce en parte y que se encuentra en la British Library, pero del que no indica signatura.
} 
con santos y santas popularmente honrados a capotazos" ${ }^{21}$. Sin embargo, antes de Pío $\mathrm{V}$ hubo otros papas que asistieron gustosos a festejos taurinos. Se sabe que León X (1513-1521) asistió a corridas y debían gustarle por las noticias que tenemos. El mismo año de su acceso al pontificado las hubo por carnaval y en 1519 también, regalando caros trajes al efecto, que lucieron por cierto dos caballeros que murieron en el festejo. Además de en Roma, hubo en Nápoles en tiempos del virrey Pedro de Toledo, que participó con brillantez en ellos en 1535/36 junto a otros nobles y tenía fama de gran toreador. Hubo asimismo en Siena y en Florencia, en esta gran ciudad incluso ya en 1584, con motivo de la visita del príncipe Vicencio Gonzaga, para honrarle. Por tanto, no fueron tan raros los festejos taurinos en la Italia del XVI y nuestro memorial los menciona incluso, aunque es verdad que siempre fueron vistos como algo no propio, "exótico", según los califica Benedetto Croce, que recoge estos eventos festivos que indicamos ${ }^{22}$. En la percepción de los mismos que tenían los italianos influyó poderosamente la idea de nación dominadora de los españoles hacia su país, y de ahí el rechazo de muchos a su celebración. El antiespañolismo del napolitano Paulo IV, el papa Caraffa, sin duda marcó en dicha percepción.

Por otra parte, en círculos romanos cercanos al pontífice, hubo personas influyentes que asesoraron e inclinaron al papa a la redacción de su célebre motu propio, y parece que informaron por escrito a Pío $\mathrm{V}$ en este sentido, algunos incluso españoles. Fueron nada menos que san Francisco de Borja, entonces General de una muy ascendente Compañía de Jesús, que tanta fuerza había tomado en España, siendo apoyada por el partido ebolista y luego papista. Aunque jesuitas residentes en España eran partidarios en general de las actuaciones del monarca, el grupo de poder jesuítico de Roma estuvo del lado del pontífice en el contexto de las tensas relaciones indicadas párrafos arriba. A Borja le asesoró en esta cuestión un jesuita antitaurino que resultó muy eficaz, Juan Quirós de Sosa. Otro santo muy opuesto a las fiestas de toros fue santo Tomás de Villanueva, cuya opinión virulenta ${ }^{23} \mathrm{se}$ recoge en la carta del cardenal Portocarrero a Carlos II, ya en 1680, con motivo del último y vano intento pontificio por prohibir las corridas ${ }^{24}$. Es posible que el origen de la influencia taurófoba en los círculos pontificios fuera española, como defiende Añoveros, pero que cobró fuerza en Roma es evidente que fue por la de los propios

${ }^{21}$ G. Santonja (2010), pp. 152, 154.

${ }^{22}$ B. Croce (1925), pp. 164-165.

23 J.M. García Añoveros (2007a), p. 213. Menciona un sermón del santo donde explícitamente se condenan las fiestas de toros.

${ }^{24}$ D. Ruiz Morales (1971), pp. 39-49. La carta fue del 25 de septiembre de 1680 y en ella se repasan las disposiciones papales sobre la cuestión. Le respondió el Consejo de Estado el 19 de octubre en el mismo sentido que el memorial que editamos, pues ante el peligro para quienes participaban se dice que "eran toreadores de officio", que se cuidaba la seguridad y que el peligro era escaso. 
círculos más cercanos al Papa, los romanos. No obstante, hubo otros religiosos españoles muy destacados en letras que actuaron a favor de ellas, como fray Luis de León, lo que se verá líneas adelante. También dio parecer en contra el nuncio ante Felipe II, el referido monseñor Castagna (1566 a 1569), arzobispo de Rosano, al que no le gustaban nada, y además algunos obispos italianos, como el de Ascoli, Pietro Camaiani (1519-1579), nuncio extraordinario del papa en 1566/67, que remitió a Roma un informe firmado por teólogos taurófobos. Precisamente, estos dos prelados criticaron mucho en su correspondencia con el papa lo que ellos juzgaban intromisión y agravios en España del poder civil al eclesiástico (Serrano, 1914, v. I: $443-446)^{25}$, siendo muy partidarios del bando ebolista-papista. Por tanto, no era sólo una cuestión de gustar o no gustar los toros. Por último, el secretario de Estado del Vaticano y sobrino del papa, cardenal Alessandrino, al que le constaba cómo poco a poco el confesionalismo filipino se iba consolidando y al que rechazaba radicalmente, también influyó no poco en el pontífice, fructificando ante el papa los pasos de todos estos opositores. Alessandrino llegó a prohibir al gobernador de Roma los festejos, bajo pena de muerte de quien los celebrara, el 17 de agosto del año de la promulgación, 1567, pero incluso meses antes de ella. Entonces, por tanto, al igual que en tiempos actuales, había razones antitaurinas ajenas a la propia realidad taurómaca y que tenían que ver no poco con la alta política y con un sentido antiespañolista. En aquel entonces, el contexto conciliar fue negativo asimismo pues en Trento los duelos y desafíos fueron taxativamente condenados, y no se olvide que la tauromaquia es en verdad una lucha de poder a poder, como eran los duelos a espada. Pero dentro del concepto de honor presente en una sociedad hispana todavía cercana al fin de la Reconquista, precisamente el concepto de pugna de poder a poder estaba muy asentado. Las ideas de fama y gloria, que venían de los siglos medievales ${ }^{26}$ en que se corrieron toros, no eran ajenas al logro y al lucimiento entre tus iguales, de ahí el gusto de los nobles por los festejos taurómacos, gusto y afición que muy pronto se hizo popular entre todas las gentes. Cabe recordar que el conde de Lemos, "pidió al rey merced de hábito de Santiago para salir a quebrar garrochones como caballero, al estarle prohibido ello siendo Grande de España", prohibición que buscaba evitar poner en riesgo la vida de lo mejor de la nobleza ${ }^{27}$.

El erudito Francisco Rodríguez Marín recopiló parte del epistolario antitaurómaco de Castagna, en un breve pero delicioso artículo, "Felipe II, taurófilo" ${ }^{28}$. A fines de junio de 1566 en carta al cardenal Alessandrini, explica que

\footnotetext{
${ }^{25}$ El primer apéndice es precisamente un memorial de agravios del poder civil hispano a la jurisdicción eclesiástica, anotado por Castagna.

${ }^{26}$ A. García Valdecasas (1948); J. Caro Baroja (1966), pp. 86-112; M.R. Lida de Malkiel (1983).

${ }^{27}$ G. Santonja (2010), p. 320, remitiendo al conde de las Navas.

${ }^{28}$ F. Rodríguez Marín (1927), pp. 55-61.
} 
el día de san Juan estaba el palacio real casi vacío por irse toda la corte a los toros. Se le encargó sondear al monarca al efecto de una prohibición pero observó, según dice en carta del 17 de junio de ese año, que letrados y juristas habían dictaminado que no eran ilícitas y el propio Felipe II le había afirmado "que no piensa que se podrían suprimir nunca en España sin grandísimo disturbio y descontento de todos los pueblos".

Pero los influjos indicados en contra de los festejos pesaron en el Vaticano, además de la propia animadversión pontificia, y se promulgó allí la bula, recibida en febrero de 1568 por el nuncio. La influencia en el santo padre de estas opiniones contrarias a la fiesta de toros se supo por parte de los defensores de la misma, de ahí que en el memorial se reitere la idea del mal asesoramiento recibido por el pontífice, aunque ya se ha indicado que éste es un leit-motiv de los memoriales de la facción castellanista. Los contrarios a la bula también entendieron que la expresión agitatio taurorum se refería a lucha directa con toros y fieras, no al toreo al modo español. El 14 de mayo escribía Castagna indicando, en una maniobra, que los Obispos son tanto del papa como de Su Majestad y sospechaba que muchos no la habían publicado y que incluso algunos escribirían a Su Santidad solicitando al menos autorización para el toreo a caballo. Coincidiendo con la gravedad del Príncipe Don Carlos, el 16 de junio escribía Castagna que se suspendían las fiestas de toros pero más por ella que por la bula. Efectivamente, una vez pasen los lutos por él y la reina es cuando, como vemos por el memorial, se plantea la necesidad de reanudar los festejos, sobre todo en el contexto de la nueva boda regia, omitiéndose el cumplimiento de la bula.

\section{Las consecuencias de la bula y la actitud de Felipe II}

Evidentemente, el motu propio no cayó en saco roto en cuanto a polémica. El Obispo de Salamanca, Jerónimo Manrique de Figueroa (1579-1593), tuvo que intervenir contra los profesores salmantinos que en sus aulas proclamaban el no pecado de la asistencia de clero y seglares, y hubo quien se aprestó a redactar tratados sesudos propios de la altura universitaria de la España del XVI, como fray Antonio de Córdoba con su De difficilis quaestionibus. Fue requerido desde Roma por parte del cardenal Alessandrino para que se abstuviese pues era muy partidario de los toros, aunque también se refiere Córdoba en su Tratado de casos de consciencia a que no se deben correr toros en días de Cuaresma, por ser días no festivos sino de tristeza ante la inminente Pasión del Señor ${ }^{29}$. Sin embargo, el

\footnotetext{
${ }^{29}$ A. de Córdoba (1592), f. 92v, en Real Biblioteca, VIII/10935, no alude directamente al correr toros pero sí en la Tabla, en $\mathrm{f}$. Rrrr $<8$. Fue obra de mucho éxito desde su primera edición en los años setenta. Las cuestiones difíciles debían ser las presentes en el Tratado de casos de consciencia pues la primera edición es de Toledo, Juan de Ayala, 1573, unos años después de la bula de 1567.
} 
portugués también franciscano fray Manuel Rodrigues, en su Summa de casos de consciencia, estima que es pecado correrlos en días de fiesta bajo excomunión pero no en los ordinarios, aunque siempre lo es para los religiosos que los ven ${ }^{30}$, siguiendo la bula de Pío V y el breve de Gregorio XIII (1575), a las que alude, recogiendo asimismo las acciones del Obispo Manrique contra quienes dijeran lo contrario. Curiosamente, se alude en Rodrigues al rumor de revocación por parte de Clemente VIII (f. 242) cuando no se produjo tal -y solo para los no regulares- hasta unos años más tarde. Baste estos dos ejemplos para referirnos a los autores que entraron en la cuestión, que fueron diversos en aquella España de teólogos y canonistas, y a los que ya se aproximaron en su día otros estudiosos (Pereda: 1945 y $1990)^{31}$. Desde el serio acercamiento del padre Pereda ha habido otros a la actitud de la Iglesia ante el hecho taurómaco, aunque hubo otros anteriores o el conde de las Navas ${ }^{32}$, pero es imposible no citar por su nivel los de Jesús María García Añoveros tanto en su completo libro El hechizo de los españoles como en su texto publicado en el volumen séptimo fruto del Aula de Tauromaquia del CEU, dedicado a la controversia en el seno de la Universidad de Salamanca ${ }^{33}$ y que califica con razón de "foco de la polémica", dada la afición entre el profesorado, hasta el punto de ir disfrazados a los festejos muchos eclesiásticos debido a las disposiciones papales y de tener que costear cada nuevo doctor, como gabela académica al uso, tres toros de muerte ${ }^{34}$. Se llegará a un punto en el que el cuerpo de doctores y maestros, según los Estatutos de 1625, debía acompañar al que se graduare en el "ir y volver de los toros", ya costumbre obligatoria. Y lo mismo pasaba en lo de sufragar el doctorando una corrida en nada menos que la Universidad de San Marcos, en el Perú.

Por otro lado, aparte políticas, es evidente que Felipe II siempre se opuso a aplicar la vigencia de la bula, de hecho consta su asistencia a festejos a lo largo de su vida. El marqués de san Juan de Piedrasalbas, en su por otra parte muy

\footnotetext{
${ }^{30}$ M. Rodrigues (1593), ff. 239-24, en Real Biblioteca, III/4996. En el segundo tomo (de 1593), cap LXXI que dedica íntegramente a los toros.

${ }^{31}$ Pereda, jesuita, fue profesor de Derecho Penal en Deusto por lo que fue una voz autorizada y aborda diversos aspectos capitales en la materia.

${ }^{32}$ M. Roumengou (1996), y J.M. Albendea (1993), pp. 103-130; Laurencín (1888). Navas (1985), pp. 103-144 y 66, que remite como origen de la materia a Juan de Mariana (SI) en su De spectaculis, dentro del TractatvsVII (Coloniae Agrippinae, 1609), véase el capítulo "Jubileo. Relaciones de la Iglesia Católica con las corridas de toros".

${ }^{33}$ J.M. García Añoveros (2009), pp. 261-290. Desgrana las prohibiciones a los eclesiásticos para asistir a los espectáculos taurinos acercándose a las distintas disposiciones pontificias, la tradición taurina de la Universidad de Salamanca, la actitud de Sixto V, la propia Universidad y el obispo Jerónimo Manrique, y el breve de 1596 donde se daba lugar al desenlace de la cuestión.

${ }^{34}$ V. de la Fuente (1887), tomo III, p. 104.
} 
interesante libro Fiestas de toros, le proclama incluso como "gran protector de las fiestas de toros y gran aficionado a presenciarlas hasta el extremo de que al fijarse en Madrid para el traslado de la corte tuvo también en cuenta que los toros más bravos se criaban en las riberas del Jarama". Cita en este dato a Mesonero Romanos $^{35}$. Por contra, Riba sitúa la realidad en sus miras de su jurisdicción y gobierno como soberano gobernante y no tanto de aficionado. Riba habla de no asistencia a festejos por desdén regio, mencionando algunos señalados por su ausencia $^{36}$, sin embargo, se sabe de otros notables en los que sí estuvo presente. De bien niño ya asistió a una corrida de toros que se celebraba en la Corredera de Valladolid, acompañado de su madre, doña Isabel. Cuando se realizó la jura del propio Felipe II, en abril de 1528, con menos de un año de edad, su padre el César alanceó toros y quebró tres lanzas en ello. No se hacía nada nuevo pues la relación entre las personas reales y los festejos taurinos era antigua. Ya en 1418 se le agasajó a Juan II de Castilla con toros al hacer su entrada en la villa de Madrid, levantándose incluso una plaza cuadrada de madera entre las Puertas de Segovia y la de la Vega. Hay muchos testimonios de asistencia de Felipe II a los festejos que no pormenorizamos aunque indicamos alguno señalado. Así, cuando su heredero y futuro Felipe III juró en la iglesia de san Jerónimo, en 1584, hubo caballeros que lidiaron toros a rejón bajo los ojos del monarca, por tanto, el propio tercer Felipe asistió también bien mozo ya a ellos, pues ese 12 de noviembre contaba con seis años. También asistió Felipe II a la fiesta de toros de Valencia, en febrero de 1586, donde se corrieron catorce toros. Referimos tan solo alguno de los festejos en los que estuvo presente, sin embargo, fueron bastantes a lo largo de toda su vida. Obviamente, que presenciara no pocas fiestas de toros, es realidad verificada suficientemente, como se observa en repertorios y obras como las del conde de Las Navas, Alenda y Mira, Díaz Arquer.

Aparte de su presencia, otra cuestión es que gustara de ellas. Si no tuvo rechazo a ellas, tampoco parece que mostrara pasión por ellas, simplemente, le guiaba un pragmatismo de gobernante dada la gran afición popular en todos los estamentos. Por un lado, bien consciente era el monarca que un punto de unión de la realeza con su pueblo y su nobleza eran los festejos taurinos -en el memorial se afirma que "es medio de congratulación de los vasallos al señor en sus uienes, sucesos y alegrías" de victorias, nacimientos y bodas reales-, aunque es cierto que hubo ocasiones en que Don Felipe no estuvo presente, pudiendo haberlo estado. Por tanto, parece que si no era gran aficionado tampoco tuvo desdén, y no se puede así afirmar ni que era taurófilo como señala Rodríguez Marín, ni que le desagradaban con rotundidad, como escribe categórico Riba. Sin embargo, el peso de la gobernabilidad con

\footnotetext{
${ }^{35}$ Le califican de taurófilo F. Rodríguez Marín o antes A. Rodríguez Villa (1886), pp. 278279. San Juan de Piedrasalbas (1928), p. 70.

${ }^{36}$ C. Riba (1963), pp. 6-11.
} 
relación al pueblo y el respeto a sus gustos festivos tan arraigados sí que pesó mucho. Con relación a la bula pontificia, es evidente que Felipe II tenía muy claro lo arraigado que estaba el festejar con toros no solo entre el pueblo y la nobleza sino entre la misma Corona y que era una novedad muy negativa la prohibición a efectos de nobleza y pueblo y sus gustos. Por ello, la actitud del soberano fue progresiva y sin embargo eficaz, primero, de ningunear a la bula sin rechazarla, luego de conseguir la declaración apostólica de Gregorio XIII, Exponi nobis (25 de agosto de 1575), para que afectara la prohibición y excomunión solo a los que hubieran recibido órdenes sacras. Con Sixto V, la excomunión pasó de ser latae sententia, -o sea, ipso facta-, a conminatoria, ferendae sententia. Por último, mediante el motu propio de Clemente VIII, Suscepti muneris (13 de enero de 1596) se derogaba el veto a los eclesiásticos "en todas las Españas", tras las acciones diplomáticas de Felipe II en Roma (Santonja: 2013, 35).

Aparte de su conciencia de gobernante del "interés general" del pueblo en sus aficiones, Felipe II muestra por escrito su lado positivo hacia los festejos. Por muestra, en el epistolario con sus hijas, tan interesante a efectos de vida privada del monarca, por recoger en él aspectos cotidianos acontecidos en el día. Estando en Lisboa, en septiembre de 1582, escribe esperando que los toros que se iban a correr al día siguiente fueran buenos y luego remitió misiva, desilusionado, afirmando que habían sido ruines ${ }^{37}$. En otra misiva, no a sus hijas, escribía el soberano "habrá cinco días que también se corrieron toros delante de Palacio, aunque no fueron muy buenos ni bravos" ${ }^{38}$. No puede extrañar así en absoluto que el Consejo Real desautorizara las prohibiciones del Obispo de Burgo de Osma, Sebastián Pérez, que en la localidad impuso el cumplimiento de la bula a rajatabla. La documentación en el Archivo Municipal de la localidad, editada en 2013 (Santonja) revela el tira y afloja que duró de 1584 a 1594 entre el Consejo y la autoridad eclesiástica, que llevaba muy mal los tradicionales festejos en la plaza de la catedral, que sin embargo se desarrollaron en ella hasta 1770. Ya en 1584 el Consejo se opuso a la disposición episcopal contra quienes corrían toros para regocijar la villa y esos documentos reflejan muy bien la actitud del Consejo Real ante la cuestión, no baladí en muchos municipios. Felipe II comunicó así a Roma, en el principio del proceso referido, que la actitud vaticana no surtía sus efectos por ser las corridas de toros una costumbre tan antigua que parecía estar en la sangre de los españoles, que no podían privarse de ella sin gran violencia. Sin embargo, el tiempo hizo que los recelos pontificios persistieran y, décadas después, hubo todavía el postrer breve de Inocencio XI, Non sine gravi gloris, exhortando otra vez a la prohibición (21 de julio de 1680), que fue asimismo excusado en su aplicación por el Consejo de

\footnotetext{
${ }^{37}$ La edición más solvente y actual del epistolario entre monarca e hijas es de Fernando Bouza (1998).

${ }^{38}$ G. Santonja (2013), pp. 44-45.
} 
Estado. En efecto, tanto nobles como pueblo llano y hombres de letras estaban muy mayoritariamente a favor de los festejos.

Ya el conde de las Navas refiere una carta, luego bastante citada, de mano de fray Luis de León y en nombre del claustro universitario, dirigida al propio Mateo Vázquez de 8 de julio de 1586, sobre el breve pontificio de Sixto V (1585-1590) por el cual podía el obispo Manrique actuar contra los eclesiásticos taurinos, rechazándole el claustro por ello ${ }^{39}$. El claustro universitario, sintiéndose ofendido por el Obispo, hizo gestiones en la corte de mano del doctor Solís, yendo al Monasterio de san Lorenzo para hablar personalmente al soberano, aunque con quien trató fue con Mateo Vázquez, no sabemos si por haberse ya ocupado de la materia. Se le pidió que no remitiera el asunto al Consejo Real para no enmarañar más, aunque procedió Vázquez como solía, preparando en el Consejo la cuestión antes de acudir al monarca con ella. En el seno del Consejo se vio complicado el asunto, se dijo que era más propio de Roma y de acudir a sus instancias, al ser el origen un breve pontificio. En 1587 fray Luis de Léon gestionó en Madrid una carta del rey para el embajador español ante el papa a través de Vázquez y que intercediera ante Sixto $\mathrm{V}$, pero en vano pues el secretario real no quería nuevo motivo de fricción a costa de la Universidad salmantina. Debía acudirse directamente a instancias romanas, en efecto., La cuestión no era la afición del profesorado religioso por los festejos y que se les permitiera asistir o no, sino los derechos jurisdiccionales del claustro, pues se entendió el breve de Sixto V instrumentalizado por el obispo Manrique como una grave intromisión jurisdiccional. Las gestiones en Roma fracasaron pese a ser intermediario el cardenal Ascasio Colonna y no vino el desenlace feliz hasta el breve de Clemente VIII de 1596, Suscepti muneris. Pese a la asistencia del profesorado clérigo, Felipe II, viendo la ilegalidad manifiesta en que se incurría con respecto a Roma, siguió con la materia y obtuvo finalmente el breve clementino, gracias a la habilidad del entonces embajador ante la Santa Sede, el duque de Sessa, insistiendo el monarca siempre en lo arraigado de los festejos taurinos, su imposible supresión y las consecuencias de la violenta situación de los clérigos. En este breve se recogen realidades presentes en el memorial, y trasladadas sin duda por el rey: la antigüedad de las fiestas de toros y el uso que hacen de ellas los hombres de armas para ejercitarse en la guerra. Se levantaba finalmente la excomunión ferendae sententiae para los clérigos, pero no para los religiosos y se insistía en no realizarse los días festivos y en que se cuidara todo para que no hubiera muertes, una de las cuestiones fundamentales del rechazo vaticano, la inutilidad de muertes que ya se habían producido en estos vanos festejos, a ojos de la curia.

${ }^{39}$ C. Riba (1963), p. 10, remitiendo a Navas (1985), pp. 110 y 127. Se halla la carta en BNE, Res. 261, nº 91, según la refiere J.M. García Añoveros (2007b), nota 17. G. Santonja (2010), p. 318, recuerda que la carta iba firmada en primer lugar por el rector Sánchez Dávila. 


\section{Tipología documental y origen de nuestro memorial}

Una vez esbozada la significación política del documento en sus contextos, el de las relaciones España-Vaticano, el de las realidades italianas, el de la actitud regia, y la cuestión de su posible autor, antes de centrarnos en las realidades taurómacas que aborda, conviene acercarnos al memorial en sí como tipología documental. Los memoriales se dirigían por lo general a muy altas instancias. Dentro de la Monarquía estaban los dirigidos a Su Majestad, que solían ser de pedimento, en solicitud de una actuación regia, por ejemplo, y tramitados a través de la Cámara de Castilla, órgano de administración de la gracia real, para obtención de alguna merced regia. Por ello, contenían una memoria de los méritos del solicitante, haciéndose memorial de los mismos. Por equivalencia, existía una variante, la de los memoriales que eran más de parecer, en los que se daba el parecer u opinión sobre una materia, y los argumentos se exponían haciendo igualmente memoria de los mismos, por lo que asimismo era un memorial y, además, el fin era el mismo, la solicitud de una actuación regia con respecto a dicha materia ${ }^{40}$. Pero por el contenido de nuestro memorial, parece evidente que iba dirigido al papa o al menos a instancias vaticanas a raíz de la bula, y acaba solicitando que no se aplique la bula pontificia o motu propio.

Por cierto, dicha bula se halla trasladada al español del latín en una copia simple existente en el mismo Archivo-Biblioteca Zabálburu ${ }^{41}$. Los fondos del Archivo-Biblioteca, de gran riqueza, han sido glosados en diversas aproximaciones $\mathrm{y}$ en al menos una tesis doctoral ${ }^{42}$. Antes de estas aproximaciones fue don Gregorio de Andrés quien explicó con su maestría habitual cómo fue a parar a los hermanos Zabálburu una parte procedente de los papeles de la casa de Altamira, donde estaban los papeles tanto de Mateo Vázquez como de don Juan de Zúñiga ${ }^{43}$. Resumiendo lo referido prolijamente por don Gregorio, hemos de indicar que al morir Mateo Vázquez pasaron sus papeles a su cuñado y asimismo secretario Jerónimo Gassol hasta que, en ese afán de Olivares de agrupar no sólo una gran biblioteca de códices y piezas bibliográficas sino un gran archivo que concentrara los de secretarios reales anteriores, pasaron a sus manos. Dada la estrecha vinculación de la privanza de gobierno con la consulta escrita, Felipe IV le concedió este propósito por dos reales cédulas bien conocidas, las de 1625 y 1632. En efecto, siempre se había sido consciente desde las altas instancias de la

\footnotetext{
${ }^{40}$ Para la tramitación de los memoriales en la Cámara de Castilla, véase en general M.J. Álvarez-Coca, 1994: 279-296, y S. de Dios (1993), pero justo poco después de 1570 hubo una reforma importante en ella: S. de Dios (1998), pp. 31-72.

${ }^{41}$ Cfr. Caja 126-doc. 1, Colección de bulas, breves y motus propios de diversos papas (s. XVI), de 1550 a 1592 , f. 63.

42 Vid. de la archivera de Zabálburu Mercedes Noviembre, 1999: 19-32. Sobre la tesis, M.T. Llera Llorente (2004) y (2005), pp. 103-128.

${ }^{43}$ G. de Andrés (1986), pp. 587-635.
} 
necesidad de tener localizados los archivos de los secretarios reales, y muchos de estos papeles llegaron a Simancas gracias al interés de Diego de Ayala, el diligente archivero de Felipe II, pero otros permanecieron en manos particulares, como los de Mateo Vázquez ${ }^{44}$. Tras los largos pleitos entre las dos casas pretendientes de herencia del conde-duque, por familia, la de Leganés y la de Medina de las Torres, pasan finalmente a la primera los legajos referidos, en 1678. Y al morir sin sucesión en 1711 el tercer marqués de Leganés, pasaron a la de los Osorio Moscoso, la casa de los condes de Altamira, siendo entonces titular el décimo, consorte de una descendiente de Olivares, hija del primer marqués de Leganés. Aparte de los ya numerosos fondos archivísticos, se incrementó así en gran cantidad el volumen de los mismos, y se continuó haciendo, pues hay que recordar la boda de la VII marquesa de Velada con Antonio Gaspar Osorio Moscoso. Gracias a esta unión se sumaron los papeles de Juan de Zúñiga, entre los que estaba el manuscrito descrito, con nuestro memorial. Esta incorporación y otros aspectos de la misma la ha comentado ampliamente Bouza ${ }^{45}$.

En la casa de Altamira permanecieron todos los papeles de Estado hasta la enajenación en 1869/70, a causa de una ruina económica que venía de décadas antes, en tiempos del XIII conde, Vicente Joaquín, amante del lujo, retratado por Goya. El palacio madrileño donde estaba el archivo, el llamado de la Flor, hubo de venderse y con él multitud de bienes, tras el agravamiento de las deudas en los años cuarentasesenta del XIX, en época ya de los XIV y XV condes. El caso es que los industriales y hombres de finanzas hermanos Zabálburu eran acreedores de los condes y finalmente hubo de resarcirse la deuda con una parte del amplísimo archivo familiar de Altamira, lo cual cuadró especialmente a Mariano y Francisco Zabálburu, los más bibliófilos y cultos de los hermanos. Por otra vía, el asesor bibliográfico de los Zabálburu, el hábil José Sancho Rayón, se hizo con parte de otro lote dispersado como papel para envolver entre comerciantes madrileños de la

${ }^{44}$ Es elocuente la carta de Gabriel de Zayas a Diego de Ayala, de Madrid, 25 de junio de 1567 sobre el paradero de algunos: “... es menester saber dónde se hallarán todos los papeles destado viejos, yo he dicho que en Cuenca los de Valdés, en Sanct Sebastián los de Ydyáquez y aquí los de Gonzalo Pérez, que aya gloria, y en Toledo algunos que se yo que tiene Vargas. V.m. me avise luego dónde están los de Cobos y de Juan Vázquez y cualesquier otros destado que v.m. entendiere que ay en estos Reynos de Castilla, que los de la Corona de Aragón ya Çurita los ha visto todos", y que recoge F. Bouza en "Guardar papeles -y quemarlos-...", p. 8, en p. 9 se reproduce otro testimonio de Ayala sobre la necesidad de recogerse estos papeles "que estuvieron en el Consejo Real y se repartieron por todos los oficios a cada uno lo que era del suyo,...".

${ }^{45}$ F. Bouza (1997), p. 11. La tenencia de la documentación de Zúñiga por la casa de Velada se debía a que el marqués de Velada, Gómez Dávila, sustituyó a Zúñiga, tras su muerte, como mayordomo mayor del futuro Felipe III, integrándose en la Junta de Gobierno en 1593 , como refiere Bouza en la página indicada. 
calle Arenal, siendo hoy ambos conjuntos un total de 571 cajas, aunque lo comprado a tenderos fue una mínima parte en comparación. Todo esto lo relata con rico detalle De Andrés, al igual que cómo fueron a parar los otros amplios depósitos archivísticos de procedencia Altamira al Instituto Valencia de Don Juan (Madrid), gracias al XIII Conde de Valencia de Don Juan, don Juan de Crooke y Navarrot, y al fondo Edouard Favre de la Universidad de Ginebra, pues un suizo, Paul Chapuy, fue durante años el último bibliotecario de la casa de Altamira. Así vino a parar nuestro memorial al Archivo-Biblioteca Zabálburu.

\section{El contenido del memorial}

En el memorial, lo primero que llama la atención al comenzar a leerlo es que, como se hace en otros muchos documentos y autores conocidos - caso de Argote de Molina y otros muchos-, se asocian las palabras fiesta y regozijo. Se empieza invocando la necesidad de los festejos taurinos con motivo de las bodas reales, los cuales siempre han existido en efecto a causa de enlaces en la Familia Real y se han mantenido luego, incluso en la boda de Alfonso XIII hubo corrida regia, para la que por cierto hizo el cartel Mariano Benlliure ${ }^{46}$. A continuación se entiende el carácter específico para España de la bula pues aunque ésta era general para toda la cristiandad, el uso habitual de los festejos taurinos era en España y sus posesiones, lo que se subraya pese a recordarse en el memorial los ya indicados festejos italianos. Se afirma que debió advertir Su Santidad al rey del interés que tenía con respecto a la cuestión del correr toros antes de llegar a emitir nada menos que una bula, y sin duda la misma fue sorpresiva en España y también en el monarca, que le hubiera informado de los aspectos de interés para el pontífice, se dice. Sin embargo, según se indica, el santo padre prefirió escuchar a personas "que puedan auerse mouido con buena intención más con poco fundamento y poca prudencia", las cuales ya hemos referido, y que no eran neutrales con respecto a la política confesionalista de Felipe II. Se les acusa en el memorial de hacer "falsa relación" por exagerarse los peligros corporales y espirituales de la práctica taurina y por callar aspectos fundamentales de la misma.

Precisamente, para que el papa tuviera argumentos imprescindibles para juzgar en verdad la realidad de los festejos, se exponen a continuación en el memorial diversas circunstancias que concurren en los mismos: primero, se destaca la antigüedad de ellos, "en tal manera que por testimonios auténticos se puede afirmar que pasa de quinientos años", siendo desarrollada esta costumbre por la expresa autoridad y aprobación de los príncipes. Han sido muchos los autores que han tratado de los orígenes y antigüedad de la fiesta taurina en España, baste recordar por un lado a los más clásicos, como el conde de Las Navas, y por otro a autores

${ }^{46}$ Hay ejemplares en la Real Biblioteca, ARCH3/CAJ/32 (18) a (21). 
actuales muy solventes, ya citados ${ }^{47}$. Casi todos coinciden, y los referidos también, en que si los romanos practicaban juegos taurinos no los trajeron a la península pues ya existían en Hispania, por tanto, se desarrollan en la península desde tiempo inmemorial y no fue actividad traída por ellos ${ }^{48}$. Añoveros recoge diversos testimonios en este sentido y su opinión es que los usos y modos en que se desarrollan los festejos desde el siglo IX, en que se tiene noticia de ellos, no tienen nada que ver con los de los romanos, siendo una manifestación totalmente autóctona. Las fechas a las que se remonta el memorial son bastante acertadas pues habla de que "pasa de quinientos años" y es de 1570, por tanto hacia el año mil, y Añoveros halla vestigios en el siglo IX. La de que el correr toros es de origen musulmán y fue práctica traída a la península tras la invasión musulmana es asimismo otra falsedad histórica que fue un lugar común en los tiempos románticos del siglo XIX. Tras aparecer en el siglo IX la tauromaquia, en el XIV se asentaría el correr toros, en el XV y XVI se extenderían los festejos y el XVII sería el período de esplendor del toreo a la antigua, caballeresco, antes de que en el XVIII ilustrado surgieran las bases de lo que hoy es el toreo moderno. Los orígenes del toreo a pie sin embargo es muy anterior, como bien se ha demostrado, desde al menos el siglo XII ${ }^{49}$ (Santonja: 2010, 2012). Dice Piedrasalbas que desde el siglo XI existían matatoros, verificados documentalmente, aunque a lo largo de todo su clásico libro refiere festejos medievales y referencia de los mismos en fueros y corpus legales. El testimonio del siglo IX, concretamente del año 815, lo aporta la Crónica de España de Alfonso X, escrita en el XIII, pero que detalla cómo cada día que duraron las Cortes de León de entonces, bajo Alfonso II el Casto, se lidiaron toros. En la Primera Crónica General de España de Alfonso X, se indica también que en el 897 se corrieron toros con motivo de unas notables bodas. Para el siglo $\mathrm{X}$ hay otras referencias, en el Poema de Fernán González.

A continuación se subraya en el memorial que es para el pueblo la mayor demostración de alegría en victorias militares, bodas y nacimientos reales y en general prósperos sucesos, siendo el "principal regozijo" que se hace. Es el festejo popular por antonomasia. Se sigue con la cuestión de la seguridad física, que preocupaba sobremanera al pontífice y su curia, y se destaca que en las plazas donde se corren, además de no permitirse estar a mujeres y niños, hay talanqueras, y personas de a caballo que socorren a los de a pie, y entre éstos los hay muy diestros, y a su vez los de a pie valen a los de a caballo, lo que muestra lo extendida que

\footnotetext{
${ }^{47}$ J.M. García Añoveros (2007ª), pp. 79-93, "Principio o desarrollo de la lidia o de correr los toros", trata de los orígenes y evolución hasta el siglo XVI, y sigue sobre cómo eran los festejos en ese siglo. En pp. 83-84 interesa "Raíz y cuna española". G. Santonja (2010, 2012).

${ }^{48}$ Navas (1985), pp. 40-45. Á. Álvarez de Miranda, en su libro fundamental (1962), trata específicamente del toro en las religiones ibéricas antiguas, ajenas al mundo romano.

${ }^{49}$ G. Santonja $(2010,2012)$.
} 
estaba la lidia a pie en 1570, siendo especialmente importante esta observación, como se señaló líneas arriba. El párrafo que sigue se dedica por entero asimismo a la seguridad que hay en los festejos y se inicia con la realidad de que todos los que intervienen lo hacen por voluntad propia pues "no son en manera alguna compelidos ni apremiados a ellos, ni aun inducidos ni rogados, y ellos salen y andan allí de su propia voluntad". Esto, que parece baladí y obvio, no es tal pues otorga singularidad al caso español, ya que por ejemplo en los juegos romanos taurinos con frecuencia los protagonizaban en los circos penados, como recordaba por entonces Juan de Mariana (S.I.), contrario al espectáculo taurino. La cuestión de la seguridad en las fiestas de toros fue polémica y suscitó la opinión de teólogos y canonistas. Martín de Azpilcueta, que era en general contrario a ellas, decía en cambio que podían permitirse si eran seguras, y esta opinión tuvo seguidores. Así, se admitía sin problemas el correrse en lugar abierto pues el peligro para el hombre estaba mucho más en coso o plaza cerrada y por ello la bula se ceñía a estos espacios cerrados.

El siguiente párrafo es de gran interés y se centra en lo unido que estaban el correr toros y el juego de cañas "muy antiguo en este Reyno, muy noble, muy particular y muy propio" y se afirma que si se quitara lo primero, el correr toros, sería el fin de las cañas pues si hay veces en que se corren toros sin que haya cañas, "las cañas no se juegan sin correr toros, ni es regozijo que se haze ni se haría sin correr toros por ser fiesta que de sí sola es muy breue, duraría muy poco y sería muy fría, y tendría poco concurso y gente a uerla", siendo indisociables las cañas de los toros. No era raro por tanto que en los libros de jineta se tratara a la vez del correr toros y de los juegos de cañas ${ }^{50}$. El juego de cañas era actividad señorial, el correr toros en cambio a la vez señorial y popular, y sobrevivió, mientras luego cayeron en desuso las cañas. Se insiste luego en el memorial en que los festejos son "política y moralmente buenos" y por tanto no hay fundamento para prohibirlos. Las que no eran morales eran las fiestas gentiles con leones y similares, se dice, pues era "locura, pecado y uestialidad" pretender que un hombre entablara lucha con estos animales, y por ello las condenaron concilios y santos. Esta cuestión de la moralidad de los festejos no fue liviana, sobre todo en una sociedad donde se hacía "caso de conciencia" de tantísimas realidades sociales y se publicaban gruesas sumas de casos de conciencia. Añoveros dedica de hecho un capítulo, el VII, a ello en su extenso libro. La bula que origina nuestro memorial condena los festejos por inmorales, en cambio, en 1575 dejaban de ser inmorales, con Gregorio XIII, si se cumplían con determinados preceptos. La actitud pontificia en cada bula y breve es fundamental pues influía en los tratadistas de cada período, así, antes o después de 1575. El enfoque de la moralidad distaba mucho del de hoy pues lo que no era moral era que estuviera en juego la vida de los participantes en el espectáculo,

${ }^{50}$ L. Toro Buiza (1944). 
preocupaba la vida humana, en cambio, en la polémica actual se pone el acento en la vida del animal frente a la humana. En efecto, hubo festejos especialmente abundantes en el número de participantes muertos, y aún así, el pueblo lo veía normal, no le importaba pues se entendía natural dada la naturaleza del espectáculo y le parecía imposible que por ello fueran suspendidos. El toreo a pie ya estaba extendido a inicios del XVII y por ello era fácil que hubiera cogidas mortales, más difíciles a caballo. En la Granada de 1609, los toros mataron en agosto en la plaza de Bibarrambla a 36 personas y en la Valladolid de 1612, a diez. Con el paso de los siglos, la Fiesta no ha hecho más que dulcificarse progresivamente, incluso en el siglo XX, con la imposición del peto para el caballo. Hubo algunos autores que se centran en el toro, pocos, frente a los que lo hacen en la vida humana y los que eran partidarios del correr toros, bastantes, que se alineaban con el sentir popular y con el autor del memorial. Todos estos autores ven la lidia lícitamente moral, por supuesto. Según los textos, "El grupo que repudiaba la fiesta siempre fue minoritario" ${ }^{\prime \prime}$.

Asimismo, se alude en el memorial a la prohibición en los cánones "en lo de torneamentis", es decir, el tornear en rieptos y desafíos entre dos caballeros, subrayándose que el correr toros era algo totalmente ajeno en sentido y forma a lo que era el correr toros, criterio no compartido en los círculos romanos, que vinculaba claramente ambas realidades y las condenaba según lo dispuesto en Trento. Se sube luego el tono defensivo y se afirma que la prohibición "sería gran nota e ynjuria de todos" ya que es fiesta tan aprobada por príncipes, hombres graves y doctos y por los consejos y tribunales, pues no es "cosa de juego o de plaçer solamente sino como punto de estado y gobierno" y es necesaria para "la salud y leticia pública y por otras consideraciones de buena policía y buen gobierno".

Se continúa con una frase un tanto confusa pero bien interesante, dándose a entender que sin la fiesta quedarían pocos toros y no habría en muchos años, además de que sin ella no habría en otro lugar festejos: "Este regozijo y fiesta pública es en España el correr de los toros, y quitándose éstos quedan tan pocos que en muchos años y en ningún lugar ay otro alguno...". Se apela al bálsamo social que suponen los festejos pues los desasosiegos populares se calman con ellos y se reafirma que son demostración de alegría popular.

El párrafo que sigue, largo, tiene enjundia argumentativa pues, dado el carácter festivo del correr toros, se centra en que se hace los días de festividades en las que se conmemoran santos y patronos, en buena lógica según el autor, pero precisamente éste es uno de los puntos capitales condenatorios de la bula de 1567, en la que se considera agravio que se hagan encima en esas fechas señaladas por la Iglesia. Frente a la muy probable sorpresa de los contrarios a los festejos, se destaca que se hacen justo esos días por devoción al santo o patrón y como demostración

${ }^{51}$ J.M. García Añoveros (2007a), pp. 237-254. 
alegre de la veneración que suscitan esos santos y patronos. Aparte argumentos, la verdad es que así se ha considerado en España siempre, de hecho, cuando siglos más tarde se implantó el ferial de san Isidro en 1947 se hizo para honrar al santo labrador patrón de Madrid, aunque ya en el siglo XV se honraba con toros a san Juan, en Madrid. Siempre que se conmemoran patronos de localidades ha habido fiesta taurina de por medio, aparte Madrid, a san José en Valencia o a la Virgen del Pilar en Zaragoza. La fiesta taurina va unida a la fiesta religiosa. Sin embargo, en la época no estaba tan claro y el tema era controvertido pues había diócesis que decidían en esos años vetar los festejos, en consonancia con Roma; el Concilio Provincial de Toledo de 1565/66 señalaba que no se santificaban a la Virgen y a los santos con toros sino con alabanzas divinas y preces. El breve de Gregorio XIII de 1575 admite incluso que se corran toros, pero no en días festivos. Este empecinamiento por los días festivos fue pernicioso para todo el mundo pues se corrían el lunes y lo que se hacía era prolongar un día más la holganza y se sabe que a lo largo de los días festivos se molestaba a los toros encorralados por parte de pícaros, valentones y matachines. Se configura así la actitud hispana como algo muy español que ha permanecido en el tiempo como vemos. Se ofrece en el memorial una defensa muy interesante para esta unión de fiesta religiosa y fiesta taurina, pues se indica que siendo los herejes cristianos contrarios a los santos, cualquier modo social de honrarlos debe ser bueno para la Iglesia: "Y, como en estos tiempos, los hereges tan ynpía y desvergonzadamente impugnan y quieren quitar lo de la beneración y cultura de los sanctos, menos ynconueniente tendría el permitirla con algún eceso y superfluidad y alimentar y fomentar por todas uías esta pía afectión en los hombres que, en tal tiempo, moderarlo seca y resfría el deuoto espíritu con que en esto se haze" ${ }^{\$ 2}$. Hubo autores en España que trataron de la cuestión y no siempre desde actitudes morales, Mariana por ejemplo rechaza que se celebraran en días festivos pero por razón práctica: porque se vaciaban las iglesias, aunque hubo otros que sí alegaron razones morales.

Se sigue en el texto que, siendo importante que en lo taurino sea fiesta o regocijo, es de mucha consideración y relevancia en lo social, pues por todo el reino los caballeros y hombres de calidad crían caballos y se ejercitan con ellos en esos días festivos en que se corren toros, siendo ello fundamental para que no se pierda la caballería a la jineta, y si no se corren toros ni salen caballeros con sus caballos "se perderá todo esto y la nobleza se yrá haçiendo ynballe [i.e. inválida] y poco ejercitada y como dormida e inerte, y no estamos en tiempo de embaraçar el

\footnotetext{
52 J.M. García Añoveros (2007a), pp. 344-355: "La lidia de los toros en los días festivos" recuerda, sin embargo, una sucesión de concilios y sínodos donde se reprueban este tipo de espectáculos en días festivos y que la cuestión seguía candente en el XVIII.
} 
exercicio militar" ${ }^{\prime 53}$. Y, por iguales motivos, es beneficioso para los hombres de a pie, pues los hombres se hacen ligeros, diestros y ágiles y se levanta el espíritu y ánimo con estos ejercicios. Un largo párrafo que sigue incide en el absurdo de prohibir una actividad por si pudiera ser peligrosa en el futuro, al realizarse, pues por igual motivo que en el caso del correr toros, así, las dagas o arcabuces pueden matar hombres y se podrían prohibir por tanto, y se podrían prohibir asimismo las comedias, bailes y juegos por no ser buenas actividades para el hombre. Por último, se subraya que se ha hecho relación falsa al pontífice en lo relativo a los peligros, daños e inconvenientes para el hombre, y que Su Santidad debe hacer por tanto suspensión de la bula.

Termina el memorial destacando la gran dificultad en observarse la misma y que ello sería, como ya se había dicho, motivo de gran escándalo. Pronto se dejó así de lado la prohibición general, haciendo caso omiso, y la cuestión se centró en la asistencia de los eclesiásticos, como se ha visto en el escenario salmantino. El que se celebraran en días festivos o no era vieja cuestión polémica pero también pasó a segundo término frente a la anterior, haciéndose igualmente caso omiso. Había una larguísima tradición en la Iglesia de prohibir la asistencia a espectáculos públicos a los clérigos y consagrados, ya desde el siglo IV (Concilio de Laodicea) y en España ya lo advertía san Isidoro en su De vita clericorum, por lo que no era materia coyuntural y exprofesa de los toros. Por ello fue la cuestión de interés y el empeño español en que no se considerara, y no se paró en las gestiones frente a la Santa Sede hasta que se logró con Clemente VIII en 1596. En abril y mayo de 1568 Castagna y Alessandrino se escribían sobre la no promulgación en España por parte de arzobispos y prelados, en sus sedes. Era conocida pero no había sido promulgada salvo en Roma. Y se debía a que muy pronto se vio en círculos cortesanos y del rey que la bula no era del agrado de Su Majestad, de hecho, pidió éste a los prelados su no promulgación mientras negociaba con Roma un cambio de la bula en sus términos. Pero no hubo por parte regia retención de la bula pues se difundió su contenido, ni se aplicó el llamado pase regio, vetándola, en derecho de los soberanos españoles ante los documentos pontificios. Este asunto de la promulgación o, mejor dicho, no promulgación, fue capital asimismo para muchos, pues estimaron que al no ser promulgada no debía ser acatada, sin embargo, ya vimos que otros muchos no distinguieron y se suspendieron festejos pese a las bodas regias, de ahí la labor real hasta ir consiguiendo la benignidad pontificia, rebajando en 1575 y en 1596, sobre todo, el carácter prohibitorio de 1567. El cardenal Alessandrino, secretario de Estado del Vaticano, se esforzó en vano para que fuera promulgada en España pues Castagna escribía en junio de 1568 que

\footnotetext{
${ }^{53}$ J. Campos Cañizares (2007). Es libro muy explicativo para la unión entre los festejos taurinos y la práctica de la caballería a la jineta en el siglo XVII el de Campos Cañizares, aunque muchas consideraciones valen también para el siglo XVI.
} 
estaba paralizada a la espera de las gestiones regias y entre tanto, no se corrieron toros, sino vacas bravas, de las que nada decía la bula. Hecha la ley, hecha la trampa, y en la práctica hubo así festejos taurinos sin quebrantar la voluntad papal. Con el tiempo, los religiosos, a lo primero recelosos dada la prohibición, pronto asistieron a ellos, como bien se comprobaba en Salamanca, y también se volvió a correr toros en festivo, "como Dios manda", se decía, y no los papas ${ }^{54}$.

Una vez que se ha comentado el memorial en sí, en su contenido, el mismo permite unas conclusiones que obviamente exceden lo taurómaco a efectos de ocio social, aunque su relevancia en la historia de la tauromaquia hispana es evidente. La primera conclusión es que pese a ser bien conocida la bula de 1567, hay que situarla para su correcta interpretación en el estado de las relaciones Monarquía HispánicaSanta Sede, en especial en tiempos del pontífice Pío V, que la promulga, y cuya cancillería vaticana la expide. A fines de los años cincuenta, coincidiendo con el asentamiento del nuevo reinado y la muerte de Carlos V, desde 1559/1560 hay un viraje ideológico de la Monarquía hacia un confesionalismo regalista independiente de las directrices romanas, las cuales toman el camino propio de la Contrarreforma y sus políticas precisamente de modo claro desde Pío V -heredero del antiespañolismo de Paulo IV en varios aspectos-, continuado al respecto por Gregorio XIII y Sixto V. En este sentido, de la cuestión de la tauromaquia se hace por parte del Papado un uso también político, partiéndose de presupuestos morales, pues dada la afición tan popular de los festejos taurómacos de toda la sociedad hispana se sabía que sería elemento de confrontación con la Corona. En la corte española había desde muy anteriormente dos facciones de poder cortesano, la ebolista, luego papista tras la muerte de Éboli y que liderará Antonio Pérez, y la castellanista, como se sabe encabezada por el duque de Alba. La cuestión taurómaca es un episodio más en este contexto de tensiones entre Madrid y Roma. El asunto no fue primero contemplado por los lutos de la reina Isabel de Valois y del príncipe don Carlos, pero en 1570 ya era asunto debatido en instancias de gobierno por las demandas populares de festejos, y es entonces cuando surge el memorial estudiado. La "guerra" de la Monarquía en pro de los festejos durará años pues tendrá varias fases, desde la prohibición total hasta una gradualidad que irá tomando laxitud y que se ha comentado líneas arriba. La lucha fue llevada con inteligencia por parte de la Corona, sabiéndose mover por parte de los embajadores hispanos ante la Santa Sede, y en ella intervinieron voces de alto nivel intelectual, ya mencionadas. Roma argüía que los festejos de toros eran inmorales para el ser humano pero los hilos que movió la Corona dieron a ver justamente lo contrario para el pueblo español, por ser una manifestación colectiva que corroboraba actitudes como el valor, la destreza, el pundonor, el heroísmo, la habilidad, el

${ }^{54}$ G. Santonja (2010), p. 163. 
sufrimiento y otras virtudes muy presentes en lo militar, tan presente en una sociedad que había construido un poder imperial en Europa a base de ganar batallas.

Aparte este contexto capital, el texto del memorial es muy relevante para la propia historia de la tauromaquia. En 1570 se indica que son fiestas que existen entre los españoles desde hacía más de quinientos años, es decir, hacia el año mil al menos, aunque se sabe que ya había en el s. IX, como se ha recogido, y se destaca su arraigo en la celebración de victorias militares y bodas y bautizos reales. Se destaca lo unida que estaba la fiesta de toros a otra muy arraigada, como era la de los festejos de cañas, y que si desaparecieran los primeros, se perdería la segunda... En aquella época, el antitaurinismo vaticano y de los tratadistas que mostraban tal, se centraba en el gran peligro para la vida humana pues siempre había algún que otro muerto en los festejos. No existía la perspectiva animalista, y, por lo anterior, en el memorial se incide en las medidas de seguridad que se tomaban. Se deja caer que sin los festejos no existirían toros y que no se concibe la celebración de fiestas religiosas de patrones locales sin ellas, en una realidad que dolía especialmente en Roma, entre los contrarios a ellas pero que en España era inseparable. Se subraya que Su Santidad ha estado mal aconsejada y que no sabe de aspectos fundamentales sobre lo beneficiosos que son estos festejos para el pueblo. La verdad es que muy pronto se vio en las instancias vaticanas que era imposible evitar su celebración popular y por ello se centró la polémica en la asistencia de religiosos regulares primero, luego de eclesiásticos en general, en el hecho de la celebración en días de precepto $\mathrm{y}$, en fin, en cuestiones de vida puramente eclesiástica frente a la batalla perdida con respecto a la sociedad en general. Y en unos años tuvo que claudicar también a estos respectos la Santa Sede, como sobre la asistencia de los propios religiosos.

\section{TEXTOS}

1

\section{Versión primigenia}

Memorial dirigido al doctor Velasco, consejero de Felipe II, en defensa de las corridas de toros. [Memorial, cerca del propio motu de S.S. en lo de los toros]. Archivo General de Simancas (Patronato Real, legajo 22-exp. 100) ${ }^{55}$.

${ }^{55}$ Pese a que el memorial primigenio fue editado en 2012 por el profesor Santonja (2012: 168-177), con edición y reproducción fotográfica del mismo, se considera capital el cotejo 
Primeramente se presupone que este propio matu (sic, motu) de la prohibición del correr los toros se expidió [sigue tachado y a veni] y vino en estas partes después del fallecimiento del príncipe y reyna, nuestros señores [precede tachado aviendo cre], estando estos reynos y los naturales dellos con el luto, tristeza y sentimiento que de tales acaezimientos se debía tener. Por razón de lo qual todo lo que era materia de fiesta y regozijo ha estado suspenso fasta agora, que con el efecto del casamiento de Su Magestad [sigue tachado es llegada la ocasión de la alegría y fiesta, regoçijos y fiestas] ha çesado el luto y la tristeza y venida la ocasión de las fiestas, alegrías y regocijos que en [precede tachado el pueblo] estos reynos se acostumbran de ordinario y en esta coyuntura particularmente se deben hazer. Y esta ha sido la causa de averse diferido esta diligençia y a esto se debe atribuyr el aver hasta agora callado y dexádose de representar a Su Magestad lo que al presente se ordena se le represente.

Este propio motu aunque en la forma y palabras sea general para toda la christiandad y provinçias della, en el efecto se entiende bien que a sido expedido y se endereça prinçipalmente a estos reynos, siendo ansí que en los otros reynos y provinçias este exerçí́o y fiesta no se vsa, excepto en Ytalia en algunas pocas partes, $\mathrm{y}$ en aquellas en muy diferente forma; $\mathrm{y}$ [precede tachado de] solo en esta provinçia de España, y aun de Castilla, es fiesta y regozijo ordinario, y ansí, no embargante que las otras provinçias callen y no reclamen por no les tocar ni les ser de importançia, en esta es tan diferente y de tan gran sustançia que no se a podido ni puede / $(f .1 v)$ pasar en disimulaçión.

Y si Su Santidad vbiera sido seruido antes de la expediçión deste propio motu y de tomar en esto determinaçión, tocando prinçipalmente a España, advertir primero a Su Magestad para que le mandara informar [sigue tachado así] de la justificaçión y fundamentos que [precede tachado con] esta costumbre de correr toros tenía y de la orden y forma con que se haze, y de todas las otras consideraçiones y circunstançias que en esto concurren, y no quisiera dar tanto crédito a personas particulares, que pueden ellos aver tenido buena intinción pero no tienen ni la autoridad ni la prudençia ni la experiençia que para hazerse fundamento en su sola relaçión era menester en vna cosa general y de la calidad e importançia que esta es, somos çiertos que Su Santidad lo mandara más mirar y entendiera quán diferente es el negoçio de lo que se le deve aver representado, y que suspendiera la determinación [sigue tachado o al menos la publ] y publicaçión deste propio motu.

textual de la versión primigenia, comentada entonces por Santonja, y la definitiva, muy ampliada, pues se comprueba la inclusión de cuestiones fundamentales en el mismo, por ello se insertan las dos. El motivo del presente estudio ha sido así fundir las visiones de Santonja y la de Moreno, conocedor éste de la versión de Zabálburu, la definitiva, desde 1994, en una interpretación conjunta. La transcripción de la primera versión corresponde al profesor Santonja y la de la versión definitiva al Dr. Moreno. Ambas transcripciones acentúan según uso moderno y desarrollan abreviaturas habituales en la época. 
Mas no embargante que se aya venido a estos términos, se debe esperar, según el santo zelo y gran prudençia de Su Santidad, que en qualquiera tiempo tendrá <lugar y fuerça $>$ acerca de su beatitud, la razón y la justa consideraçión y mandará pooner remedio en aquello cuya execuçión trahería muchos inconvinientes. Y para que $\mathrm{Su}$ Santidad entienda el hecho y vea [precede tachado conozca] quán falsa relaçión se le a hecho, así en lo que se le ha dicho como en lo que se le ha dexado de dezir, se le podrá advertir de lo que aquí se dirá:

Lo primero es bien que Su Santidad entienda que esta costumbre de correr toros en estos reynos por fiesta y regozijo es en ellos antiquísima, en tal manera que por auténticos testimonios se puede afirmar aver más de quinientos años que se vsa, y es vna fiesta y costumbre muy general, so solo en los lugares grandes y prinçipales, mas ansimismo en los pequeños y aldeas, / $(f .2 r)$ y que es regozijo ordinario en çiertos días de cada año. Y asimismo en las otras ocasiones extraordinarias de demostraçión de alegría, como en los casamientos de los prínçipes, nasçimientos de sus hijos, nuevas venidas dellos a los lugares, buenas nuevas de victoria, o otros feliçes suçesos. Y es esto de correr los toros vn género de fiesta [sigue tachado que no solo es ] mayor, <la mejor y más prinçipal de todas las $>$ que [precede de $\sin$ cancelar y todas las tachado ] en estos reynos se hazen, y en tal manera que, quitada ella, cesa quasi del todo el plazer, regozijo y fiesta del pueblo.

Esta costumbre, que como esta dicho es antiquísima, general y ordinaria y en provinçia tan christiana y de reyes tan chathólicos (sic), no ha corrido [sigue tachado solamente con sabiduría [...]pre] <este discurso de tanto tiempo con sola sabiduría $>$, permisión y disimulaçión de los prínçipes y de sus consejos y tribunales, mas asimismo con expresa autoridad y aprobaçión, interviniendo en las tales fiestas, dando liçençia y orden para que se hagan y mostrando su consentimiento y aprobaçión por todos los otros medios. Y la antigüedad desta costumbre y la autoridad que le han dado prínçipes tan christianos y el crédito [sigue tachado solamente con sabiduría [...]pre] que se [sigue tachado debe ] $<$ debería $>$ de tener de sus consejos y tribunales, en que concurren personas tan christianas, graves y doctas, $\mathrm{y}$ ser [precede tachado ser en ] y aver sido en provinçia de tanta religión y christiandad, quando no se viniese a razones particulares, era de mucha consideraçión para no ser condenada con tanta nota de todos, pues se presupone [sigue tachado que o han] que o han pecado con maliçia o han herrado con gran ignorancia. Lo qual ni puede dexar de sentirse ni de representarse, espeçialmente no aviendo sido oýdos ni entendídose su razón.

En el correr de los toros en estos reynos, para que no suçeda el daño y peligro que a Su Santidad se debe aver referido, se han hecho y hazen muchas [precede tachado muy buenas ] y muy buenas prevençiones por las justiçias y personas que lo goviernan, haziéndose talanqueras, reductos y lugares donde se aseguren y recojan los que andan al toro, proveyendo que los niños y mugeres y otras personas impedidas no estén en la plaça, / $(f .2 v)$ veyéndose [precede tachado provene pro] primero por sus personas y haziendo sus pregones, ordenando que anden en la plaça 
alguaziles y personas para lo prevenir y executar. Demás desto, en las plaças concurre [sigue tachado ordin] muy ordinariamente $<$ mucha $>$ gente de cavallo, que guarece a los de a pie, y los de a pie se faboreçen los vnos a los otros, y entre ellos ay muchos muy diestros y animosos que lo hazen muy fáçilmente, y no se va a combatir ni lidiar con el toro (como se debe aver presupuesto) cara a cara ni temerariamente, y los que lo hazen son algunos que tienen tanta destreza y están con tanta seguridad que entre mill no suçede a vno peligro, y los demás lo hacen [sobrescrito y tachado $<$ todos $>$ ] de lexos [sigue tachado y podiéndos] y de donde se pueden fáçilmente saluar. Y como quiera que no embargante todas las dichas prevençiones, suçeda [prece tachado no pudiendo ser] en algunos peligro de ser muertos o heridos, porque en tanto concurso de gente no se puede del todo escusar, mas el peligro y daño es pocas vezes y no es con mill partes el que a Su Santidad se debe aver encareçido, y aquel no es por culpa de los que goviernan y dan a esto autoridad, teniéndolo prevenido, de manera que si no es por grande negligençia o culpa de los hombres a quien suçede el caso, no ay ni puede aver [sigue tachado el dic] el tal peligro.

En el correr de los toros pueden concurrir, como es muy ordinario, gente de a cavallo y de a pie. Los de a cavallo es cosa sin duda que no corren sus personas ningún género de peligro, no solo los que andan en la plaça aparte sin acometer ni esperar al toro, pero ni asimismo los que le acometen y esperan, y solo corren el peligro de herirles o matarles el cavallo, y en el discurso de çien años no se abía [precede tachado ha visto ] visto aver peligro dos personas. Y demás de que estos de a cavallo puedan andar y salir al toro sin peligro y sin inconviniente, es el exerçiçio en sí muy bueno y muy loable de destreza y de ánimo y muy propio de hombres y de caballeros [sigue tachado y en que no solo] y que no solo deue [en el margen izquierdo, en sentido vertical, se escribió la dirección: Doctor Velasco. En el siglo XVIII se puso la siguiente nota archivistica: Sobrel correr de los toros. Falta parte; $y$ en el siglo XX se escribió esta otra: Sin año] / (f. 3r) [......].

\section{Versión definitiva}

Memorial en lo del propio motu que prohiue el correr de los toros (1570). Archivo-Biblioteca Francisco de Zabálburu: fondo Altamira, caja 241expediente 37

Presupónese que como quiera que este motu propio en que Su Santidad prohíbe lo de los toros, a muchos días que se expidió y publicó, que se tiene del acá notiçia como en estos reynos después del fallecimiento del príncipe y Reyna nuestros señores a hauido el luto, tristeza y sentimiento que era razón, todo lo que a sido materia de fiesta o regozijo a cesado y se a suspendido. No solo en el hazerllo pero 
aun en el tratarse dello, fasta agora que a tenido a efecto el casamiento de su Magestad y con el la obligación de haber en el reyno la demostración de fiestas y regocijos que se deue, y de introduçir las ordinarias que en él se acostumbra, entre las quales es la más común y prinçipal ésta de los toros. Lo qual se advierte para escusar la dilaçión que a auido en no se auer hecho esta diligençia antes y para que se entienda la causa porque se a callado y disimulado, no enbargante que, desde luego que se tuuo notiçia del dicho motu propio se entendiere los ynconuenientes que de la execuçión del resultarían.

Este propio motu en las palabras y en la forma es general para toda la cristiandad y prouincias della, en el efecto es solo para estos reynos porque en las otras prouinçias no se usa este género de fiesta eçepto en algunas pocas partes de Italia y en ellas a muy diferente modo. En este reyno es muy general, y muy ordinaria, a quien principalmente toca, y ansi, aunque por los otros reynos y prouinçias no se aya reclamado por que no les ua nada ni les ymporta, lo deste Reyno es de muy diversa razón y de otra importancia, en el qual, por el graue perjuicio e ynconueniente no se a podido ni puede (f. 380v) pasar en disimulación.

Y si Su Santidad uuiera sido seruido, pues esto tocaua y se hacía principalmente por España, primero que tomara determinación y hiziera publicación de este motu propio, [hubo] aduertir a su Majestad de la relaçión que en esto de correr los toros tenía. Y del escrúpulo e ynconueniente que la representación que en ello auia, su Majestad lo uuiera mandado ynformar de todo lo que en esto pasaua y de la orden y forma que en ello se tenía y de los justos fundamentos y razones que auia de las consideraciones, y otras cincunstançias que en ello concurren. Lo qual todo entendido se deue a que Su Santidad lo mandara más mirar y no proçediera a esta determinación y publicación, ni diera tanto crédito a personas particulares que puedan auerse mouido con buena intención más con poco fundamento y poca prudencia, espeçialmente no siendo aquella desta la autoridad ni experiencia que su testimonio y opinión pudiese ser bastante para negoçio tan general y desta calidad. Y como quiera que sea no embargante la dicha determinación y publicación, se deue con razón esperar del sancto zelo y gran prudencia de Su Santidad que açerca de su beatitud, en cualquiera término, tendrá su fuerça y su lugar la raçón y justa consideración lo mandará reueer y remediar.

Y puesto que auiéndose hecho, a Su Santidad, falsa relaçión por los dichos particulares a cuya relaçión este propio motu emanó, como se entiende auersele hecho encareciendo y exajerando los peligros e ynconuenientes del cuerpo y del anima muy diferentemente de lo que en la verdad pasa y es. Y con esto juntamente, auiendose dexado de decir y representar a Su Santidad, así en el echo como en la justificación del, muchas causas y consideraciones que con raçón mouieron el ánimo de $\mathrm{Su}$ Santidad a otra determinación. Y según (f. 381) los motiuos y fundamentos sobre que el dicho motu propio se funda, proueyondose [i.e. proveyéndose] bastantemente en el escusar los peligros y daños a que Su Santidad tiene fin, pudiera su Magestad, sin entender que contrauenía a la mente y ánimo de 
Su Santidad y al fin principal del dicho motu propio, permitir que se corriesen los dichos toros como por el reyno en general y por muchos lugares del en particular se le a suplicado. Todavía por el gran respeto y ueneración que a Su Santidad tiene y por la autoridad de aquella Santa Sede, a querido que se ocurra a Su Santidad y se le represente así, en el echo para que entienda uerdaderamente como es, como en la importancia y calidad del negoçio, para que pueda más considerar lo que en ello ua, y asimismo en la justificaçión de la causa para satisfacción del escrúpulo lo que aquí se dirá:

En el hecho, primeramente se a de presuponer que esta costumbre de correr toros, en este reyno, es antiquísima, en tal manera que por testimonios auténticos se puede afirmar que pasa de quinientos años, la qual costumbre, en el discurso de tanto tiempo, no solo a corrido con tolerancia o disimulación de los prínçipes y sus consejos y tribunales, y los otros estados y géneros de hombres, mas con espresa autoridad, consentimiento y aprouación, ynteruiniendo por sus personas en las dichas fiestas, dando licencia y aun ordenando que se hiziesen e interponiendo por otros muchos medios su autoridad y aprouación en ello, los quales príncipes como es notorio an sido muy christianos y temerosos de Dios y an tenido en sus consejos y tribunales personas graues, doctas y cristianas y a sido en reyno de tanta religión y christiandad.

Esta fiesta y uso de correr toros en este reyno de más de ser muy antigua $(f$. $381 v$ ) como está dicho, a sido muy común y general en los lugares principales y grandes y en los pequeños y aldeas y a sido ordinario en cada año en dias çiertos y señalados, según la diversa costumbre de los lugares y en los casos exordinarios de demostración de alegría, como en los casamientos de los príncipes, nacimientos de sus hijos, en uitorias y prósperos sucesos y otros casos semejantes y es el más antiguo y el más común, más general y principal regozijo que en ello se haze.

Corrense los toros en las plaças y lugares públicos, auiendo preuenido las justiçias y personas que gobiernan, para eso son, el peligro y daño y para la seguridad de los que en esto ynteruienen de talanqueras, redutos y lugares donde puedan estar y se puedan acoger los que en esta fiesta estuuieren, reviniendo ansimismo de que en las tales plaças y lugares donde se corren los toros no estén mugeres ni niños ni otras personas ympedidas. Concurren espeçialmente en los lugares principales en esta fiesta personas a caballo que puedan acorrer [i.e. socorrer] y ualer a los de a pie, y los de a pie ansimismo son muchos y entre ellos ay hombres muy diestros que con seguridad y facilidad valen y defienden del toro a los otros, de manera que si algún peligro o daño sucede ni es de parte de la fiesta ni de aquellos a cuyo cargo es el proveerlo, sino por culpa grande de aquel a quien suçede el caso.

Los que corren los toros y andan en el coso o plaça donde se haze la fiesta no son en manera alguna compelidos ni apremiados a ellos, ni aun inducidos ni rogados, y ellos salen y andan allí de su propia voluntad. Estos ni lidian ni conuaten con el toro, así solos y cara a cara como se debió presuponer, y aunque algunos que 
tienen en esto ánimo y destreza le esperan, sauense desuiar y herirle con facilidad y seguridad, y causimamente suçeden dichos peligros. Los demás, todos comúnmente andan lejos y en partes y lugares donde ay buena disposiçión ( $f$. 382). Buena disposiçión para acogerse y el peligro y daño de más de ser como está referido por culpa suya es en mil partes menos del que se deue ayer representado. Son pocos toros los muy brauos y dellos se guardan bien y tienen lugar para hazerlo.

Con esta fiesta y regozijo de los toros anda como conjunto y casi como dependiente del otro, que es el juego de las cañas, lo qual en tal manera depende de los toros que aunque estos se corran muchas ueçes sin jugar cañas más las cañas no se juegan sin correr toros, ni es regozijo que se haze ni se haría sin correr toros por ser fiesta que de sí sola es muy breue, duraría muy poco y sería muy fría, y tendría poco concurso y gente a uerla. El qual regoçijo y exerçiçio de jugar las cañas es ansimismo muy antiguo en este Reyno, muy noble, muy particular y muy propio desta prouinçia y naçión y se deue entender y presuponer que quitándose los toros se quita ansimismo la dicha fiesta y ejercicio de las cañas.

Por lo que está en el hecho referido, que es lo que uerdaderamente pasa, se puede sactisfacer a cualquier escrúpulo que se aya mouido en esta materia y a los motiuos y fundamentos desta prohibición, pues el peligro y el daño no es el que se a representado. Y para que aquel no suçeda está sufiçientemente preuenido, y la causa y culpa ni está en el acto ni en los que le permiten, sino en la misma parte que uoluntaria o temerariamente se le toma, y la ocasión del pecado del que se expone a este peligro no es dada sino receuida, o tomada por el que se expone a ello. Y no siendo el acto de correr los toros en sí malo ni de género malo, y los fines porque se haze según auajo se declaran política y moralmente buenos, porque en él pueda auer peligro o daño u ocasión de pecado tomado uoluntariamente, y estando en mano de cada uno escusarlo y preuenido de parte de los que lo ordenan y permiten lo necesario para escusarlo, no pareçe que queda fundamento $(f .382 v)$ para prohibirlo. $\mathrm{Y}$ siendo los actos humanos que de si no son malos pero, por voluntad, culpa o temeridad de los que los tratan, puede aun en ellos exceso, daño o pecado, se an de prohibir, se puede discurrir casi por todos los más uoluntarios en que abrá más peligro y más ocasión de peligro y daño que en este, como se podría poner ejemplo en el nauegar, en el caminar y cabalgar a caballo, en la caça, en los exerciçios, en la corrida de muchos mantenimientos y casi en todos los otros humanos actos uoluntarios e indiferentes pues en todos ellos puede auer este esceso y desorden por uoluntad y culpa de los hombres con mucho mayor peligro y daño.

El compeler y apremiar a los hombres que lidiasen con las uestias fieras por fiesta y regozijo de los príncipes que lo mandauan fue barbara e injustísima costumbre de los gentiles y justamente condenada por los santos. El pelear los hombres aunque fuese de su uoluntad con uestia fiera temerariamente y con euidente peligro como si quisiese un hombre salir a combatir con un león o con una 
onza ${ }^{56}$ mano a mano sería locura, pecado y uestialidad, y que justamente no se deue permitir y estos son los casos en que verdaderamente hablaron los conçilios y los sanctos. En el correr de los toros ni ynteruiene lo uno, ni lo otro, y es diferentísimo caso como de la relación del uerdadero hecho resulta.

La prohiuición de los cánones en lo de torneamentis es diferentísimo porque en aquel exerciçio el peligro era más çierto e yneuitable y el acto de sí en la concertación y pugna de un hombre con otro, pudiéndose herir o matar, no podía ser sin hyra y ánimo de hazer daño al próximo. Y por el consiguiente, sin pecado en el correr de los toros ni la uestia, porque es uestia, ni el hombre en la matar, y el peligro no solo no es cierto mas no sucede sin gran culpa suya, y así el caso no solo no es semejante mas diuersísima razón.

(f. 383) El condenar una costumbre tan antigua en estos reynos que a sido no solo tolerada pero autorizada y aprouada por príncipes tan cristianos y por personas tan graues y doctas como las de sus consejos y tribunales y en común consentimiento de todos los estados de un reyno tan christiano y religioso no puede ser sin gran nota e ynjuria de todos pues se presupone e ynfiere de esta prohiuición e damnación del acto que o an todos pecado con maliçia o obrado con crasa ynorançia que lo uno y otro toca en la autoridad y buena estimaçión y se puede y deue con razón sentir.

Y presupuesto lo que está dicho en el hecho y en la sactisfaçión del escrúpulo y motiuos del propio motu para que demás desto se entienda de la importancia que este negoçio es y los ynconuenientes que en este Reyno resultarían de la obseruançia deste propio motu, y que no se deue de juzgar y estimar como cosa de juego o de plaçer solamente sino como punto de estado y gobierno se deua primero considerar que en todas las repúblicas bien gobernadas siempre se tuuo por cosa no solo conveniente mas aún necesaria el ynstituyr y introduçir en el pueblo fiestas y regozijos públicos para la alegría, para el entretener, para el diuertir de otros pensamientos, para conciliar y conservar en el amor con sus señores y gobernadores y para la salud y Leticia ${ }^{57}$ pública y por otras consideraciones de buena policía y gobierno. Este regozijo y fiesta pública es en España el correr de los toros y quitándose éstos quedan tan pocos que en muchos años y en ningún lugar ay otro alguno y el pueblo priuado destas fiestas y regozijos a que era costumbrado estaría con no poca tristeza, soledad y melancolia y como quiera que por este poco tiempo que a durado la cava ${ }^{58}$ de la tristeza por el dicho fallecimiento de las personas reales sean entretenido con la esperanza de que se tornarían a hazer. Uisto que esto pasaua adelante y se les quitaua la esperanza de permitírselo $(f .383 v)$ tendrían gran

\footnotetext{
${ }^{56}$ J. Casares (1966), p. 600, "Mamífero carnicero de tamaño mayor que el de un perro y parecido a éste en el aspecto".

57 J. Casares (1966), p. 508, "letífico, ca: adj. Que alegra”, viene del latín laetitia.

${ }^{58}$ J. Casares (1966), p. 171. Sinónimo de "foso, fosa".
} 
sentimyento y sería muy dificultoso de ympedirles que no lo hiziesen o de uenir por esta causa en alguna manera desasosiegos y en otros ynconuenientes que con los dichos regozijos y fiestas públicas se pretenden escusar.

La demostración de alegría que el pueblo en las fiestas y regozijos haze en los casamientos, naçimientos de hijos, prósperos sucesos de sus príncipes, nueuas uenidas y entradas en los lugares, es un testimonio de amor y un reconocimiento del señorío, y un medio de congratulación de los vasallos al señor en sus uienes, suçesos y alegrías muy comúnmente y muy necesario y de mucha consideración para no le quitar, y que insensiblemente tiene más efecto del que se puede explicar, y como en estos reynos, por lo que está ya dicho, esta fiesta, regozijo y demostración de alegría principalmente se halle por medio desto de los toros, quitando esto se consigue el dicho ynconueniente y es no de poco perjuizio ni ymportançia.

Déuese ansimismo aduertir que este regozijo de correr toros en estos Reynos se a hecho y haze en días solenes de santos para celebrar su fiesta y para se alegrar en estos días en ueneraçión de los santos. Y aun en algunas partes y lugares se haze por particular abito y deuoción. Y como quiera que esto a pareçido y pareçe que ofende las pías orejas de algunos, pareciéndoles que los santos no andan ni onrrados ni sus fiestas solenizadas con regozijos tan profanos, y espeçialmente con aquellos en que puede ynteruenir daño de los hombres, o deramamyento de sangre u ocasión de pecado, mas, con todo esto, queriéndose bien considerar, no se puede al menos condenar la pía efectión e deuoción de los que lo an hecho y hazen. Ni dexa de tener en alguna manera fin justificado, pues los santos no solo la iglesia tiene en su beneración y memoria ynstituydo lo de las vigilias y ayunos en las $(f .384)$ uísperas de sus fiestas, con imitación de su penitençia, y para disponer mejor el espíritu para su beneración soleniza sus fiestas en alabanza suya y gloria de Dios en los ofiçios diuinos. Mas, con esto juntamente, de mas de ordenar que en sus fiestas se uaque de los ofiçios y ministerios serviles, es muy santo y loable costumbre entre los cristianos de se alegrar los tales días y benerar los santos y celebrar sus fiestas con uestirse mejor, con alegrarse y regocijarse en las tales fiestas, y, como en estos Reynos el mayor regozijo y demostración de alegría sea esto del correr los toros, pía afectión a sido de los que con este fin lo hazen, queriendo mostrar en estos días por la beneración de los santos la última alegría y reconocimiento que pueden mostrar dello. Y, como en estos tiempos, los hereges tan ynpía y desvergonzadamente impugnan y quieren quitar lo de la beneración y cultura de los sanctos, menos ynconueniente tendría el permitirla con algún eceso y superfluidad y alimentar y fomentar por todas uías esta pía afectión en los hombres que, en tal tiempo, moderarlo seca y resfría el deuoto espíritu con que en esto se haze.

Lo que está dicho, es y deue ser en mucha consideraçión tomando esto del correr los toros tan solamente como fiesta o regozijo. Demás de lo qual tiene este negoçio otra consideración de mucha importancia, para lo qual deue de presuponer que es cierto y sin ninguna duda que en los más lugares principales de este Reyno 
los caballeros y hombres de calidad crían y sostienen caballos y se exerçitan en ello y están aperçeuidos y preuenidos para estos días de fiestas particulares en que se corren toros, y juegan cañas. Y que en tal manera es esto ansy $(f .384 v)$ que quitándoles esta ocasión y neçesidad destas fiestas y la uerguença de no estar aperçeuidas ni apunto para ellas, ni sostendrán caballos ni se exercitarán, y se perderá la caballería de la gineta y en pocos días se perderá todo esto y la nobleza se yrá haçiendo ynballe [i.e. inválida] y poco ejercitada y como dormida e ynerte, y no estamos en tiempo de embaraçar el exercicio militar. Seguir para todas partes será neçesario, antes deberíamos por todos medios provocarle y ayudarle desto en el mismo acto de los toros: el esperarlos y matarlos a cauallo es destreza y ánimo y muy de hombres y sin ningún peligro de la persona, que quando esto solo se ympidiese era de mucho ynconueniente y del quitar los toros como está en el hecho referido resulta çesar el exerciçio y fiesta del juego de cañas, tan noble y tan antiguo, y por el consiguiente, este exerciçio militar tan neçesario.

Y no solo corre el dicho ynconueniente en lo de la caballería pero ansimismo en los que corren los toros, aquí en el qual exerciçio y fiesta no se puede dudar que los hombres se hazen ágiles, ligeros y diestros y que es acto y exerciçio en que se levanta el ánimo y espíritu y se consiguen otros efectos y provechos que en razón de policía y gobierno son muy considerables.

Y como quiera que todo lo que está dicho es de mucha importancia, se representa en este negoçio deste propio motu ynconueniente mucho mayor, porque si en los toros queda si son seculares y entre personas legas, porque en ellos pueda ynteruenir peligro de uida o otro daño o ocasión de pecado, Su Santidad yntroduce hazer constituciones generales y concertadas sobre las mismas. Fundamentos podrá del todo usurpar la juridiçión temporal y proueer en todo lo que es della, pues con el mismo título y color y aún con mayor, podrá hazer constitución o propio motu para que en este reyno no se trajesen armas o algún género ( $f$. 385) dellas como dagas o arcabuces, porque con ellas se matan los hombres y con ellas se haze más daño en el cuerpo y en el ánima que no con los toros, y podría ansimismo proueer en los reynos temporales. $\mathrm{Y}$ en quanto a los legos, en todas aquellas cosas que los príncipes y leyes humanas ponense preueniendo a peligro y daño que los hombres pueden reçeuir en las uidas, personas y en las haçiendas de los otros hombres de las casas o de los edificios de los mantenimientos. $\mathrm{Y}$ así se podría discurrir por ynfinitos otros ejemplos, y el prohibir los actos seculares y entre legos quede si no son malos por la ocasión del pecado, que con la flaqueça o maliçia de los hombres puede en ellos ynteruenir. Aún sería muy más largo pues en este fundamento podría hazer constituciones y dar propios motus para prohibir entre los legos los juegos, los uayles, las comedias, y ansí en todos los otros actos y exerciçios humanos, especialmente los voluntarios y abriéndose esta puente assí materia toda la juridiçión temporal, lo qual aun en estos tiempos y según las pretensiones y presupuestos que anpliando y estendiendo su poder se toma. Y en la particular condiçión de Su Santidad, que mouido de su zelo ua tan adelante en estas materias 
es más peligroso y para mirar mucho más en ello y este punto que es el de más sustançia. Se pone aquí para advertir a los que an de ynteruenir en el remedio deste negoçio y para que entiendan lo que por todas consideraciones esto ymporta, entendiendo bien que para con Su Santidad en este punto último que obre en si puede o no puede, y en materia de juridiçión se deue de oyr con gran recato y aduertençia porque no haga el negoçio preeminencia y autoridad y se meta en él más dificultad.

Y en quanto toca al remedio y a lo que se deue a Su Santidad, pedir y suplicar y en la manera que esto se deue guiar sobre presupuesto, que esto en todo caso de una manera o de otra se a de remediar. Pareçe que se deue hazer muy principal fundamento con Su Santidad en que la relación que se le a hecho del peligro, daños e ynconuenientes $(f .385 v)$ a sido falsa. Y que para escusar los dichos peligros está muy suficientemente proueido, y ofreçiéndole de nueuo, para allanarle más en esta parte, que Su Magestad y su consejo mandarán de nueuo proueer todo lo que sea neçesario para euitar el peligro y daño y que Su Santidad lo remita y confíe. Y sobre este fundamento podía hazer Su Santidad la suspensión o declaración de propio motu o por general breue o por particular dirigido a Su Magestad, si le pareciere más decente y proueniente término, o usando de alguna manera de suspensión o título de querer tener más información y entenderlo mejor. Y, por lo menos, allando las censuras por representar a Su Santidad todo lo que está dicho y tan justas razones y consideraciones como en esto concurren, es de creer que se deua pedir lo remediar, e quitando este ympedimento, lo qual de más de lo que en sí ymporta, perseuerando todauia Su Santidad en el rigor del dicho propio motu, abriga gran dificultad en poderse aquel observar, y esto cause el escándalo e ynconueniente que tanto resultaría.

\section{Obras citadas}

AlbendeA, Juan Manuel, "La Iglesia Católica y los toros", en Revista de Estudios Taurinos. Sevilla: Fundación de Estudios Taurinos, 1993, pp. 103-130.

Álvarez-CocA, María Jesús, "La Cámara de Castilla: Secretaría de Gracia y Justicia”, en Cuadernos de Historia Moderna, no 15 (1994), pp. 279-296.

ÁlvareZ De MirAndA, Ángel, Ritos y juegos del toro. Madrid, Taurus, 1962.

ANDRÉS, Gregorio de, "La dispersión de la valiosa colección bibliográfica documental de la Casa de Altamira", en Hispania, XLVI, n 164, (1986), pp. 587-635.

BouZA, Fernando, "Guardar papeles -y quemarlos- en tiempos de Felipe II. La documentación de Juan de Zúñiga (Un capítulo para la historia del fondo de Altamira)", en Reales Sitios, XXXII, no 129, y n 131 (1997), pp. 3-33.

BouZA, Fernando, ed., Cartas de Felipe II a sus hijas. Madrid, Turner, 1988 pero ed. corregida y aumentada en Akal, 1998, diversas paginaciones. 
Bullarum diplomatum et privilegiorum..., Augustae Taurinorum, Sebastiano Franco, 1862, vol. VII, pp. 630-631, se edita el texto completo de la bula pontificia.

CAMPos CAÑIZARES, José, El toreo caballeresco en la época de Felipe IV. Técnicas y significado socio-cultural, Sevilla, Universidad-Fundación Real Maestranza de Caballería de Sevilla, 2007, diversas paginaciones.

CARO BAROJA, Julio, "El honor en la sociedad española de los siglos XVI y XVII", en La ciudad y el campo, Madrid-Barcelona, Algafuara, 1996, pp. 86-112.

CASARES, Julio (1966), Diccionario ideológico de la lengua española, Barcelona: Gustavo Gili, $2^{\mathrm{a}}$ ed., 1966.

CóRdOBA, Antonio de (OFM), Tratado de casos de consciencia, Alcalá de Henares, a costa de Juan de Sarriá, 1592, f. 92v.

Croce, Benedetto, España en la vida italiana durante el Renacimiento, Madrid, Mundo Latino, 1925, pp. 164-165.

Dios, Salustiano de, Gracia, merced, y patronazgo real. La Cámara de Castilla entre 1474 y 1530, Madrid, Centro de Estudios Constitucionales, 1993, diversas paginaciones.

Dios, Salustiano de, "Las luchas por la administración de la gracia en el reinado de Felipe II. La reforma de la Cámara de Castilla, 1580-1593", Annali di Storia moderna e contemporanea, $\mathrm{n}^{\circ} 4$ (1998), pp. 31-72.

FERNÁNDEZ CONTI, Santiago, "La nobleza cortesana: Don Diego de Cabrera y Bobadilla, tercer conde de Chinchón”, Martínez Millán (Dir.), La corte de Felipe II, Madrid, Alianza Editorial, 1994, pp. 229-270.

Fuente, Vicente de la, Historia de las universidades, colegios y demás establecimientos de enseñanza, Tomo III, Madrid, Imp. Viuda e Hija de Fuentenebro, 1887, p. 104.

GARCía AÑoveros, Jesús María, El hechizo de los españoles. La lidia de los toros en los siglos XVI y XVII en España e Hispanoamérica. Historia, sociedad, cultura, religión, derecho, ética, Madrid, Unión de Bibliófilos Taurinos, 2007a, caps. X-XI.

García AÑoveros, Jesús María, La bula de Pío $V$ De salute gregis de 1 de noviembre de 1567. Cuadernos de Tauromaquia $\mathrm{n}^{\circ}$ 14, Madrid, San Pablo CEU, 2007b, pp. 279-290.

García AÑoveros, Jesús María, "La Universidad de Salamanca, foco de la polémica los eclesiásticos y los toros en el siglo XVI", en Rafael Cabrera (Ed.), Tiempos y espacios de la Tauromaquia. Madrid, CEU Ediciones, 2009, pp. 261-290.

GARCÍA GARCÍA, Bernardo J., "Coloquios, máscaras y toros en las fiestas señoriales de un valido. El significado político y patrimonial de las representaciones al duque de Lerma", en Aurelia Ruiz Sola (Coord.), Teatro y poder. VI y VII jornadas de Teatro, Burgos, Universidad de Burgos, 1998, pp. 143-172.

García VAlDECASAS, Alfonso, El hidalgo y el honor, Madrid, Revista de Occidente, 1948, diversas paginaciones. 
GonZAlo SÁnChez-Molero, José Luis, "Mateo Vázquez de Leca, un secretario entre libros. El escritorio", Hispania, vol. LXV, n 3, (septiembre-diciembre 2005), $\mathrm{n}^{\circ} 221$, en pp. 817-818.

LAURENCín, Francisco R. Uhagón, Marqués de, La iglesia y los toros. Antiguos documentos religioso-taurinos sacados a la luz, Madrid, [ed. del autor], 1888. Tirada de cien ejemplares, diversas paginaciones.

Lida De MAlKIEl, María Rosa, La Idea de Fama en la Edad Media Castellana, México, FCE, 1983 (1952), diversas paginaciones.

LOVETT, Albert, "Cardinal's papers: the rise of Mateo Vázquez de Leca", English Historical Review, LXXXVIII (1973), pp. 241-261.

LOVETT, Albert, Philip II and Mateo Vázquez de Leca: the Government of Spain (1572-1592). Genève, Librairie Droz, 1978, diversas paginaciones.

Llera LlORENTE, María Teresa, La Biblioteca Francisco de Zabálburu, una referencia importante en la cultura de España, Madrid, UCM, 2004 tesis doctoral), diversas paginaciones.

Llera LlORENTE, María Teresa, "El estudio de los fondos de la Biblioteca Francisco de Zabálburu", en Revista General de Información $y$ Documentación, vol. 15, no 2 (2005), pp. 103-128.

MARIANA Juan de (SI), "De spectaculis", en Tractavs VII. Nunc primum in lucem editi, Coloniae Agrippinae, sumptibus Antonij Hierati, 1609, capítulo "Jubileo. Relaciones de la Iglesia Católica com las corridas de toros".

MARAÑóN, Gregorio, "Antonio Pérez y la Iglesia", en Antonio Pérez (El hombre, el drama, la época), Madrid: Espasa-Calpe, 1947, vol. I, pp. 119-143.

MARTíneZ MiLlán, José, "En busca de la ortodoxia: el Inquisidor General Diego de Espinosa", en Martínez Millán (Dir.), La corte de Felipe II, Madrid, Alianza Editorial, 1994, pp. 189-228.

MARTíneZ Millán, José (Coord.), La configuración de la Monarquía Hispánica, Salamanca, Junta de Castilla y León, 1998, vol. preliminar a la edición de Luis Cabrera de Córdoba, Historia de Felipe II, Rey de España, Salamanca, Junta de Castilla y León, pp. 103-131, 219-223, y otras diversas paginaciones.

NAVAS, Juan Gualberto López-Valdemoro, Conde de las, El espectáculo más nacional, Madrid, COCULSA, 1985 (facsímil de 1900), pp. 112-113, 129.

NoviEMBRE, Mercedes, "Biblioteca de Francisco de Zabálburu: del siglo XIX al XXI", en Pliegos de Bibliofila, no 6 (1999), pp. 19-32.

PEREDA, Julián (SJ), Los toros ante la Iglesia y la Moral, Bilbao, Ediciones Vita, 1945, y tercera edición ampliada en Bilbao, Ediciones Mensajero, 1990, diversas paginaciones.

PÉREZ RioJA, José Antonio, "Un insigne visontino del siglo XVI, Juan López de Velasco (1530-1598)", en Celtiberia, no 8 (1958), pp. 7-38.

PiZARRo, Henar, Un gran patrón en la corte de Felipe II. Don Gaspar de Quiroga, Madrid, Universidad de Comillas, 2004, diversas paginaciones. 
RIBA, Carlos, "Felipe II y las corridas de toros", Gacetilla de la Unión de Bibliófilos Taurinos, $\mathrm{n}^{\mathrm{o}} 17$ (1963), pp. 6-11.

Rodrigues, Manuel, (OFM), Summa de casos de consciencia, Salamanca, Juan Fernández, 1594, v. II, cap. LXXI.

RodríGueZ MARÍN, Francisco, Cuentos escogidos, Madrid, Biblioteca Giralda, 1927, pp. 55-61.

RodRíGUEZ VILLA, Antonio, La corte y la monarquía de España en los años de 1636 y 37. Colección de cartas inéditas e interesantes, seguidas de un apéndice con curiosos documentos sobre corridas de toros en los siglos XVII y XVIII, Madrid, Luis Navarro, 1886, pp. 278-279.

Roumengou, Marc, L'eglise et la corrida. Prohibitions et participation active, Madrid, [s.n.], Imp. Faresco, 1996, diversas paginaciones.

RUIZ MORALES, Diego, "De los juegos de toros, cañas y despeñadero", Gacetilla de la Unión de Bibliófilos Taurinos, $\mathrm{n}^{\circ} 15$ (1962), pp. 23-26.

Ruiz Morales, Diego, "El último intento papal en pro de la suspensión de las fiestas de toros: Inocencio XI y su gestión en dicho sentido", en Documentos histórico taurinos exhumados y comentados, Madrid, [s.n.] Artes Gráficas Arges, 1971, pp. 39-49.

SAn JuAn De Piedrasalbas, Bernardino de Melgar y Abreu, Marqués de, Fiestas de toros. Bosquejo histórico, Madrid, [s.n.], 1927 (A. Marzo), diversas paginaciones.

SANTONJA GÓMEZ-AgERO, Gonzalo, Luces sobre una época oscura del toreo (El toreo a pie del siglo XVII). León, Editorial Everest, 2010, diversas paginaciones.

SAntonja Gómez-Agero, Gonzalo, "Felipe II y los toros", en El Cultural de El Mundo, 2-8 de diciembre de 2011.

SANTONJa GÓMEZ-Agero, Gonzalo, Por los albores del toreo a pie (Imágenes y textos de los siglos XII-XVII), León, Editorial Everest, 2012, pp. 167-177.

SAntonja Gómez-Agero, Gonzalo, La justicia del Rey. Felipe II y el Consejo Real a favor de los toros (El Burgo de Osma, 1584-1594), Madrid, Unión de Bibliófilos Taurinos, 2013, diversas paginaciones. Hay edición de mercado, aparte de ésta de bibliofilia de 200 ejemplares.

SERrano, Luciano (OSB), Correspondencia diplomática entre España y la Santa Sede durante el Pontificado de San Pío V, Roma, Junta para Ampliación de Estudios e Investigaciones Científicas Roma : Escuela Española, 1914, vols. I-IV, v. I, pp. 443-446.

TORO BuIZA, Luis (1944), Noticias de los juegos de cañas reales tomadas de nuestros libros de gineta, Sevilla [s.n.], Imprenta Municipal, diversas paginaciones.

VARELA, Javier, La muerte del rey. El ceremonial funerario de la Monarquía española (1500-1885), Madrid, Turner, 1990, p. 35. 